\title{
Epstein-Barr virus is the cause of rheumatoid arthritis
}

\author{
Katarina Barukčić1, Jan Pavo Barukčić2 , Ilija Barukčić ${ }^{3}$ \\ ${ }^{1}$ Medical University, Sofia, Bulgaria \\ ${ }^{2}$ Department of Mathematics and Computer Sciences, University of Münster, Münster, Germany \\ ${ }^{3}$ Internist, Horandstrasse, DE-26441 Jever, Germany
}

\begin{abstract}
Aim. Many studies presented some evidence that EBV might play a role in the pathogenesis of rheumatoid arthritis. Still, there are conflicting reports concerning the existence of EBV in the synovial tissue of patients suffering from rheumatoid arthritis. This systematic review assesses the causal relationship between Epstein-Barr virus (EBV) and rheumatoid arthritis (RA) for gaining a better understanding of the pathogenesis of RA.

Methods. This systematic review and meta-analysis aim to answer among other questions the following: Is there a cause effect relationship between Epstein-Barr virus and rheumatoid arthritis? The method of the conditio sine qua non relationship was used to proof the hypothesis without Epstein-Barr virus no rheumatoid arthritis. In other words, if rheumatoid arthritis is present, then Epstein-Barr virus has to be present too. The mathematical formula of the causal relationship k was used to proof the hypothesis, whether there is a cause effect relationship between Epstein-Barr virus and rheumatoid arthritis. Significance was indicated by a p-value of less than 0.05 .

Results. The studies analysed were able to provide convincing evidence that Epstein-Barr virus is a necessary condition (a conditio sine qua non) of rheumatoid arthritis. Furthermore, the studies analysed provide impressive evidence of a cause-effect relationship between Epstein-Barr virus and rheumatoid arthritis.

Conclusion. EBV infection of human synovial tissues is a conditio sine qua non, a conditio per quam of rheumatoid arthritis. In other words, Epstein-Barr virus is the cause of rheumatoid arthritis.
\end{abstract}

Keywords: Epstein-Barr virus, rheumatoid arthritis, causal relationship

\section{INTRODUCTION}

Rheumatoid arthritis (RA), a systemic, predominantly (1) CD4+ T helper type 1 (Th1)-driven disease characterized by an extensive synovial hyperplasia and infiltration by macrophages, monocytes, lymphocytes and fibroblasts. Rheumatoid arthritis is a destructive, chronic and debilitating arthritis and can cause systemic complications. RA affects more or less about $1 \%$ of the world's population (2). The prevalence of rheumatoid arthritis in men is twofold to fourfold less $(3,4)$ than in women. The long-term prognosis of rheumatoid arthritis remains very poor. In particular, the average life expectancy of RA patients is reduced by 3 to 18 years (5). The direct costs of treatment of RA, the loss of employment and the indirect costs of disability due to RA are very high $(6,7)$. At present there is no known cure for rheumatoid arthritis, an adequate use of various kinds of disease-modifying anti-rheumatic drugs may achieve complete remission in about $30-50 \%$ of RA patients. Many exposures investigated as possible risk factors for the development of rheumatoid arthritis such as dietary (antioxidants) factors (8) red meat protein (9), fat intake $(10,11)$ breast feeding, the use of oral contraceptives or hormone replacement therapy (12) have shown no strong associations. Only cigarette smoking (13) has been found to increase the risk of rheumatoid arthritis. In the quest to uncover the unknown etiology of rheumatoid arthritis, viruses including Epstein-Barr virus (EBV), human herpesvirus-6, human herpesvirus-8, parvovirus (14) B19 (B19), HTLV-1, and human endogenous retroviruses- 5 have all been hypothesized for many years to be involved in the pathogenesis of rheumatoid arthritis $(15,16)$.

Epstein-Barr virus (EBV) is an ancient, ubiquitous virus determined by a $184 \mathrm{kbp}$-sized, double-stranded DNA genome which has infected probably more than $90 \%$ of the world's population (17). Many studies presented some evidence suggesting 
that especially EBV might play a role in the pathogenesis of RA. Among them Alspaugh and Tan (1819) were one of the first. RA patients have higher levels of serum antibodies against EBV (20-24) than normal individuals. However, due to conflicting reports concerning the existence of EBV in the synovial tissue of RA patients a cause or the cause of rheumatoid arthritis remains unknown.

\section{MATERIAL AND METHODS}

RA is an autoimmune disease characterized by progressive and more or less persistent inflammation of joints of human body. At present, prognosis of RA may be very poor in the absence of an appropriate early treatment (25) with disease-modifying antirheumatic drugs (DMARDs) like methotrexate, sulphasalazine, azathioprine, antimalarials, gold-containing compounds, D-penicillamine and cyclosporin. In particular, an additional short-term duration treatment with corticosteroid is expected to prevent progressive course of RA with erosive joint damage and functional impairment.

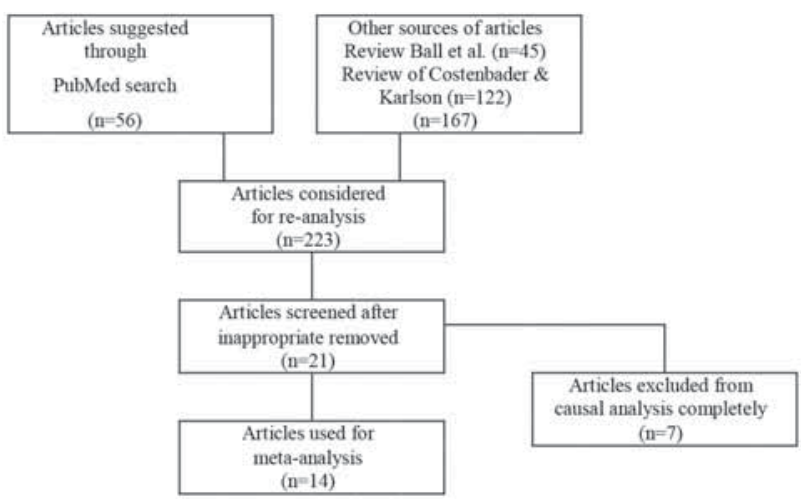

FIGURE 1. Studies identification in search strategy. Adopted from PRISMA 2009 Flow Diagram (Moher26 et al., 2009; Liberati27 et al., 2009)

\section{Statistical analysis}

All statistical analyses were performed with Microsoft Excel version 14.0.7166.5000 (32-Bit) software (Microsoft $\mathrm{GmbH}$, Munich, Germany). In order to increase the transparency, to correct some of the misprints of former publications and to simplify the understanding of this article several of the following lines are repeated sometimes word by word and taken from my former publications.

\section{The 2x2 Table}

The meaning of the abbreviations at, bt, ct, $\mathrm{dt}, \mathrm{Nt}$ of the data table used are explained by a 2 by 2 -table (Table 1).
TABLE 1. The sample space of a contingency table.

\begin{tabular}{|c|c|c|c|c|}
\hline & & \multicolumn{2}{|c|}{$\begin{array}{l}\text { Conditioned Bt } \\
\text { (Outcome) }\end{array}$} & \multirow[t]{2}{*}{ Total } \\
\hline & & Yes $=1$ & Not $=+0$ & \\
\hline \multirow{3}{*}{$\begin{array}{l}\text { Condition At } \\
\text { (risk factor) }\end{array}$} & Yes =+1 & at & bt & At \\
\hline & Not $=+0$ & $\mathrm{ct}$ & $\mathrm{dt}$ & $\underline{A t}$ \\
\hline & Total & $\mathrm{Bt}$ & $\underline{B} t$ & $\mathrm{Nt}$ \\
\hline
\end{tabular}

In general it is $(\mathrm{at}+\mathrm{bt})=\mathrm{At},(\mathrm{ct}+\mathrm{dt})=\underline{\mathrm{At}},(\mathrm{at}+\mathrm{ct})=$ $\mathrm{Bt},(\mathrm{bt}+\mathrm{dt})=\underline{\mathrm{Bt}}$ and $\mathrm{at}+\mathrm{bt}+\mathrm{ct}+\mathrm{dt}=\mathrm{Nt}$. Equally, it is $B t+\underline{B t}=A t+\underline{A t}=N t$. In this context, it is $p(a t)=p(A t$ ÇBt $), p(A t)=p(a t)+p(b t)$ or $p(A t)=p(A t C ̧ B t)+p(b t)$ $=p(A t C ̧ B t)+p(A t C ̧ B t)$ while $p(A t)$ is not defined as $p(a t)$. In the same context, it is $p(B t)=p(a t)+p(c t)=$ $\mathrm{p}(\mathrm{At}$ ÇBt $)+\mathrm{p}(\mathrm{ct})$ and equally in the same respect $\mathrm{p}(\underline{\mathrm{B}} \mathrm{t})=1-\mathrm{p}(\mathrm{Bt})=\mathrm{p}(\mathrm{bt})+\mathrm{p}(\mathrm{dt})$.

Furthermore, the joint probability of At and $\mathrm{Bt}$ is denoted in general by $\mathrm{p}(\mathrm{At}$ ÇBt). Thus far, it is $\mathrm{p}(\mathrm{At}$ $\mathrm{C} B t)=p(A t)-p(b t)=p(B t)-p(c t)$ or in other words it follows clearly that $p(B t)+p(b t)-p(c t)=p(A t)$. In general, it is $\mathrm{p}(\mathrm{at})+\mathrm{p}(\mathrm{ct})+\mathrm{p}(\mathrm{bt})+\mathrm{p}(\mathrm{dt})=1$.

\section{The data of the studies analysed}

The data of the studies analysed are presented by several tables (Table 2, Table 4, Table 6, Table 7, Table 8, Table 9, Table 10, Table 11). The meaning of the abbreviations at, bt, ct, dt, Nt of tables is explained by a 2 by 2 -table (Table 1 ) too. Some studies provided self-contradictory data (Table 3, Table 5) and were not considered for a re-analysis.

\section{Independence}

In the case of independence of At and Bt it is generally valid that

$$
\mathrm{p}\left(\mathrm{A}_{\mathrm{t}} \cap \mathrm{B}_{\mathrm{t}}\right) \equiv \mathrm{p}\left(\mathrm{A}_{\mathrm{t}}\right) \times \mathrm{p}\left(\mathrm{B}_{\mathrm{t}}\right)
$$

\section{Exclusion (At Excludes Bt and Vice Versa Rela-} tionship)

The mathematical formula of the exclusion relationship (28-48) (At excludes Bt and vice versa) of a population was defined as

$$
\begin{aligned}
p\left(A_{t} \mid B_{t}\right) & \equiv \frac{b_{t}+c_{t}+d_{t}}{N_{t}} \\
& \equiv 1-p\left(a_{t}\right) \\
& \equiv p\left(b_{t}\right)+p\left(c_{t}\right)+p\left(d_{t}\right) \\
& \equiv p\left(c_{t}\right)+\left(1-p\left(B_{t}\right)\right) \\
& \equiv p\left(b_{t}\right)+\left(1-p\left(A_{t}\right)\right) \\
& \equiv+1
\end{aligned}
$$

and used to proof the hypothesis: At excludes Bt and vice versa. 
TABLE 2. Without EBV VCA IgG positivity no RA.

\begin{tabular}{|c|c|c|c|c|c|c|c|c|c|c|c|c|c|}
\hline Study Id & Year & Country & \begin{tabular}{|l|} 
Risk \\
Factor
\end{tabular} & Case_P & Case_T & Con_P & Con_T & $k$ & $p$-val & $X^{2}$ (SINE) & $\mathrm{X}^{2}(\mathrm{IMP})$ & $X^{2}\left(I M P^{\wedge} S I N E\right)$ & $X^{2}(E X C L)$ \\
\hline $\mathrm{Ng}$ et al. & 1980 & UK & \begin{tabular}{|l} 
EBV \\
VCA IgG \\
\end{tabular} & 59 & 64 & 41 & 50 & 0.1540205 & 0.06110335 & 0.32 & 16.40 & 16.72 & 87.70 \\
\hline Ferrell et al. & 1981 & USA & \begin{tabular}{|l} 
EBV \\
VCA IgG
\end{tabular} & 76 & 80 & 45 & 51 & 0.1242185 & 0.09875740 & 0.15 & 16.37 & 16.52 & 118.36 \\
\hline $\begin{array}{l}\text { Venables } \\
\text { et al. }\end{array}$ & 1985 & UK & \begin{tabular}{|l|} 
EBV \\
VCA IgG \\
\end{tabular} & 37 & 38 & 23 & 26 & 0.1807168 & 0.15549847 & 0.01 & 8.44 & 8.44 & 57.26 \\
\hline Yao et al. & 1986 & UK & \begin{tabular}{|l} 
EBV \\
VCA IgG
\end{tabular} & 31 & 33 & 24 & 26 & 0.0322235 & 0.37703844 & 0.07 & 10.04 & 10.11 & 45.10 \\
\hline $\begin{array}{l}\text { Shirodaria } \\
\text { et al. }\end{array}$ & 1987 & UK & \begin{tabular}{|l|} 
EBV \\
VCA IgG
\end{tabular} & 26 & 26 & 24 & 26 & 0.2 & 0.24509803 & 0.01 & 11.05 & 11.05 & 38.01 \\
\hline $\begin{array}{l}\text { Youinou } \\
\text { et al. }\end{array}$ & 1992 & France & \begin{tabular}{|l|} 
EBV \\
VCA IgG \\
\end{tabular} & 98 & 100 & 49 & 50 & 0.0000000 & 0.44893887 & 0.02 & 16.00 & 16.02 & 159.73 \\
\hline $\begin{array}{l}\text { Blashke } \\
\text { et al. }\end{array}$ & 2000 & Germany & \begin{tabular}{|l|} 
EBV \\
VCA IgG \\
\end{tabular} & 55 & 55 & 53 & 60 & 0.2437490 & 0.00881473 & 0.00 & 25.52 & 25.53 & 81.51 \\
\hline Us et al. & 2011 & Turkey & \begin{tabular}{|l|} 
EBV \\
VCA IgG \\
\end{tabular} & 85 & 85 & 48 & 50 & 0.1598871 & 0.13543394 & 0.00 & 16.96 & 16.97 & 137.69 \\
\hline $\begin{array}{l}\text { Sherina et } \\
\text { al., } 2017\end{array}$ & 2017 & Sweden & \begin{tabular}{|l|} 
EBV \\
VCA IgG \\
\end{tabular} & 970 & 987 & 679 & 700 & 0.0424232 & 0.02949588 & 0.28 & 279.18 & 279.45 & 1522.31 \\
\hline & & & Total & 1437 & 1468 & 986 & 1039 & & & 0.8597 & & & \\
\hline & & & & \multicolumn{2}{|l|}{ Alpha $=$} & 0.05 & & & & & & & \\
\hline & & & \multicolumn{3}{|c|}{$\begin{array}{l}\text { Degrees of freedom (d. } \\
\text { f.) = }\end{array}$} & 9 & & & & & & & \\
\hline & & & \multicolumn{3}{|c|}{$X^{2}$ Critical (SINE) $=$} & 16.919 & & & & & & & \\
\hline & & & \multicolumn{3}{|c|}{$X^{2}$ Calculated (SINE) $=$} & 0.8597 & & & & & & & \\
\hline
\end{tabular}

Case_P: cases, positive; Case_T: cases, total; Con_P: controls, positive; Con_T: controls, total.

TABLE 3. EBV VCA IgG self-contradictory data, not considered for a meta-analysis.

\begin{tabular}{|c|c|c|c|c|c|c|c|c|c|c|c|c|}
\hline Study Id & Year & Country & \begin{tabular}{|l|} 
Risk \\
Factor \\
\end{tabular} & Case_P & Case_T & Con_P & Con_T & k & $X^{2}$ (SINE) & $\mathrm{X}^{2}(\mathrm{IMP})$ & $X^{2}(I M P \wedge S I N E)$ & $X^{2}(E X C L)$ \\
\hline Phillips et al. & 1976 & USA & \begin{tabular}{|l} 
EBV VCA \\
$\lg G$
\end{tabular} & 31 & 33 & 32 & 33 & -0.0727393 & 0.07 & 15.75 & 15.82 & 42.96 \\
\hline Nakabayshi & 1981 & Japan & \begin{tabular}{|l|} 
EBV VCA \\
IgG \\
\end{tabular} & 32 & 32 & 15 & 15 & \#DIV/0! & 0.01 & 4.47 & 4.48 & 52.12 \\
\hline $\begin{array}{l}\text { Venables } \\
\text { et al. }\end{array}$ & 1981 & UK & $\begin{array}{l}\text { EBV VCA } \\
\lg G\end{array}$ & 94 & 100 & 32 & 33 & -0.0574427 & 0.30 & 7.88 & 8.18 & 156.81 \\
\hline Musiani et al. & 1987 & Italy & \begin{tabular}{|l|} 
EBV VCA \\
IgG \\
\end{tabular} & 35 & 35 & 40 & 40 & \#DIV/0! & 0.01 & 20.80 & 20.81 & 49.88 \\
\hline Zhang et al. & 1993 & Finland & $\begin{array}{l}\text { EBV VCA } \\
\lg G\end{array}$ & 50 & 50 & 49 & 49 & \#DIV/0! & 0.01 & 23.76 & 23.77 & 73.76 \\
\hline $\begin{array}{l}\text { Mousavie-Jazi } \\
\text { et al. }\end{array}$ & 1998 & Sweden & \begin{tabular}{|l|} 
EBV VCA \\
IgG \\
\end{tabular} & 27 & 28 & 12 & 12 & -0.10482848 & 0.01 & 3.39 & 3.40 & 43.09 \\
\hline Zhang et al. & 1999 & China & \begin{tabular}{|l} 
EBV VCA \\
IgG
\end{tabular} & 75 & 91 & 38 & 45 & -0.02544181 & 2.64 & 12.44 & 15.08 & 110.11 \\
\hline $\begin{array}{l}\text { Jorgensen } \\
\text { et al. }\end{array}$ & 2008 & Denmark & \begin{tabular}{|l|} 
EBV VCA \\
IgG \\
\end{tabular} & 31 & 33 & 238 & 245 & -0.0585413 & 0.07 & 209.69 & 209.76 & 31.65 \\
\hline \multirow[t]{2}{*}{$\begin{array}{l}\text { Lünemann } \\
\text { et al. }\end{array}$} & 2008 & USA & $\begin{array}{l}\text { EBV VCA } \\
\text { IgG } \\
\end{array}$ & 25 & 25 & 20 & 20 & \#DIV/0! & 0.01 & 8.45 & 8.46 & 37.35 \\
\hline & & & Total & 400 & 427 & 476 & 492 & & & & & \\
\hline
\end{tabular}

When using data to perform some analysis, several conditions must be taken into consideration. Unfortunately, not all data are appropriate for detailed analysis. Due to formal mathematical requirements it is possible to identify data as self-contradictory and it is necessary to exclude these data from further analysis. The reason for the self-contradiction of the data is marked in bold numbers/letters. These studies were not considered for further analysis even if all these studies supported the hypothesis without EBV VCA IgG sero-positivity no RA. The term \#DIV/0! denote the case that there is a division by zero. 
TABLE 4. Without EBV EBNA IgG positivity no RA.

\begin{tabular}{|c|c|c|c|c|c|c|c|c|c|c|c|c|c|}
\hline Study Id & Year & Country & $\begin{array}{l}\text { Risk } \\
\text { Factor }\end{array}$ & Case_P & Case_T & Con_P & Con_T & k & $p$-val & $X^{2}(\mathrm{SINE})$ & $\mathrm{X}^{2}(\mathrm{IMP})$ & $\mathrm{X}^{2}(\mathrm{IMP} \wedge \mathrm{SINE})$ & $X^{2}(E X C L)$ \\
\hline $\begin{array}{l}\text { Ferrell et } \\
\text { al. }\end{array}$ & 1981 & USA & $\begin{array}{l}\text { EBV } \\
\text { EBNA-1 } \\
\text { IgG }\end{array}$ & 83 & 83 & 47 & 53 & 0.26884692 & 0.002921342 & 0.00 & 16.63 & 16.64 & 134.36 \\
\hline $\begin{array}{l}\text { Shirodaria } \\
\text { et al. }\end{array}$ & 1987 & UK & $\begin{array}{l}\text { EBV } \\
\text { EBNA-1 } \\
\text { IgG }\end{array}$ & 23 & 26 & 21 & 26 & 0.10660036 & 0.227268212 & 0.24 & 9.55 & 9.79 & 30.98 \\
\hline $\begin{array}{l}\text { Youinou } \\
\text { et al. }\end{array}$ & 1992 & France & $\begin{array}{l}\text { EBV } \\
\text { EBNA-1 } \\
\text { IgG }\end{array}$ & 90 & 100 & 41 & 50 & 0.11338681 & 0.078226412 & 0.90 & 12.52 & 13.42 & 141.25 \\
\hline $\begin{array}{l}\text { Mousavi- } \\
\text { Jazi et al. }\end{array}$ & 1998 & Sweden & $\begin{array}{l}\text { EBV } \\
\text { EBNA-1 } \\
\text { IgG }\end{array}$ & 27 & 28 & 10 & 12 & 0.22783558 & 0.187044534 & 0.01 & 2.44 & 2.45 & 44.06 \\
\hline $\begin{array}{l}\text { Blashke } \\
\text { et al. }\end{array}$ & 2000 & Germany & $\begin{array}{l}\text { EBV } \\
\text { EBNA-1 } \\
\text { lgG }\end{array}$ & 48 & 55 & 51 & 60 & 0.03280399 & 0.200258806 & 0.77 & 25.76 & 26.53 & 63.81 \\
\hline $\begin{array}{l}\text { Lünemann } \\
\text { et al. }\end{array}$ & 2008 & USA & $\begin{array}{l}\text { EBV } \\
\text { EBNA-1 } \\
\text { IgG }\end{array}$ & 21 & 25 & 16 & 20 & 0.05198752 & 0.284334686 & 0.49 & 6.49 & 6.98 & 28.17 \\
\hline Erre et al. & 2015 & Italy & $\begin{array}{l}\text { EBV } \\
\text { EBNA-1 } \\
\text { lgG }\end{array}$ & 69 & 77 & 40 & 58 & 0.25916219 & 0.002049224 & 0.73 & 14.31 & 15.04 & 103.99 \\
\hline
\end{tabular}

\begin{tabular}{|c|c|}
\hline Alpha $=$ & 0.05 \\
\hline $\begin{array}{l}\text { Degrees of freedom (d. } \\
\text { f.) }=\end{array}$ & 7 \\
\hline $\mathrm{X}^{2}$ Critical (SINE) $=$ & 14.0671 \\
\hline$X^{2}$ Calculated (SINE) $=$ & 3.1435 \\
\hline
\end{tabular}

Case_P: cases, positive; Case_T: cases, total; Con_P: controls, positive;

Con_t: controls, total.

TABLE 5. EBV EBNA IgG self-contradictory data, not considered for a meta-analysis.

\begin{tabular}{|l|l|l|l|l|l|l|l|l|l|l|l|l|}
\hline Study Id & Year & Country & Risk Factor & Case_P & Case_T & Con_P & Con_T & k & $X^{2}$ (SINE) & $X^{2}$ (IMP) & $X^{2}$ (IMP^SINE) & $X^{2}$ (EXCL) \\
\hline Sculley & 1986 & Australia & $\begin{array}{l}\text { EBV EBNA-1 } \\
\text { IgG }\end{array}$ & 49 & 72 & 41 & 49 & $-\mathbf{0 . 1 7 5 6 2 5}$ & 7.03 & 18.23 & 25.26 & $\mathbf{5 8 . 8 1}$ \\
\hline $\begin{array}{l}\text { Musiani } \\
\text { et al. }\end{array}$ & 1987 & Italy & $\begin{array}{l}\text { EBV EBNA-1 } \\
\text { IgG }\end{array}$ & 35 & 35 & 40 & 40 & \#DIV/0! & $\mathbf{0 . 0 1}$ & 20.80 & 20.81 & 49.88 \\
\hline Davis et al. & 1999 & Australia & $\begin{array}{l}\text { EBV EBNA-1 } \\
\text { IgG }\end{array}$ & 39 & 50 & 35 & 43 & $\mathbf{- 0 . 0 4 1 9 8 6 6 3}$ & $\mathbf{2 . 2 1}$ & 16.08 & 18.29 & 49.68 \\
\hline $\begin{array}{l}\text { Jorgensen } \\
\text { et al. }\end{array}$ & 2008 & Denmark & $\begin{array}{l}\text { EBV EBNA-1 } \\
\text { IgG }\end{array}$ & 29 & 33 & 231 & 245 & $\mathbf{- 0 . 0 8 4 2 1 0 6 1}$ & $\mathbf{0 . 3 7}$ & 204.35 & 204.72 & 27.74 \\
\hline Us et al. & 2011 & Turkey & $\begin{array}{l}\text { EBV EBNA-1 } \\
\text { IgG }\end{array}$ & 85 & 87 & 50 & 50 & $\mathbf{- 0 . 0 9 2 2 7 3}$ & $\mathbf{0 . 0 3}$ & 18.15 & 18.18 & 134.96 \\
\hline $\begin{array}{l}\text { Yazbek } \\
\text { et al. }\end{array}$ & 2011 & Brazil & $\begin{array}{l}\text { EBV EBNA-1 } \\
\text { IgG }\end{array}$ & 127 & 140 & 130 & 143 & $\mathbf{- 0 . 0 0 3 3 7 1 9 4}$ & $\mathbf{1 . 1 2}$ & 65.25 & 66.37 & 176.57 \\
\hline & & Total & 315 & 345 & 486 & 521 & & & & & \\
\hline
\end{tabular}

The reason for the self-contradiction of the data above is marked in bold numbers/letters. . These studies were not considered for further analysis even if most of these studies supported the hypothesis without EBV EBNA IgG sero-positivity no RA. \#DIV/0! denotes the case that there is a division by zero. 


\section{Necessary Condition (Conditio Sine Qua Non)}

The mathematical formula of the necessary condition relationship (28-48) (conditio sine qua non) of a population was defined as

$$
\begin{aligned}
p\left(A_{t} \leftarrow B_{t}\right) & \equiv \frac{a_{t}+b_{t}+d_{t}}{N_{t}} \\
& \equiv p\left(a_{t}\right)+p\left(b_{t}\right)+p\left(d_{t}\right) \\
& \equiv p\left(a_{t}\right)+\left(1-p\left(B_{t}\right)\right) \\
& \equiv+1
\end{aligned}
$$

and used to proof the hypothesis: without At no Bt .

\section{Sufficient Condition (Conditio per Quam)}

The mathematical formula of the sufficient condition relationship (28-48) (conditio per quam) of a population was defined as

$$
\begin{aligned}
p\left(A_{t} \rightarrow B_{t}\right) & \equiv \frac{a_{t}+c_{t}+d_{t}}{N_{t}} \\
& \equiv p\left(a_{t}\right)+p\left(c_{t}\right)+p\left(d_{t}\right) \\
& \equiv p\left(d_{t}\right)+p\left(B_{t}\right) \\
& \equiv+1
\end{aligned}
$$

and used to proof the hypothesis: if At then $\mathrm{Bt}$.

\section{The $X^{2}$ Goodness of Fit Test of a Necessary}

\section{Condition}

Under conditions where the chi-square goodness (8-48) of fit test cannot be used it is possible to use an approximate and conservative (one sided) confidence interval known as the rule of three. Using the continuity correction, the chi-square value of a conditio sine qua non distribution before changes to

$$
\chi^{2}(\mathrm{~S} I N E) \equiv \frac{\left(\mathrm{c}_{\mathrm{t}}-\left(\frac{1}{2}\right)\right)^{2}}{\left(\mathrm{~B}_{\mathrm{t}}\right)}+0=0
$$

\section{The $X^{2}$ Goodness of Fit Test of the Exclusion}

\section{Relationship}

The chi square value with degree of freedom $2-1=1$ of the exclusion relationship (28-48) with a continuity correction can be calculated as

$$
\chi^{2}(\mathrm{EXCL})=\frac{\left(-\left(\mathrm{a}_{\mathrm{t}}\right)-0,5\right)^{2}}{\mathrm{~A}_{\mathrm{t}}}+\frac{\left(-\left(\mathrm{a}_{\mathrm{t}}\right)-0,5\right)^{2}}{\mathrm{~B}_{\mathrm{t}}}
$$

The chi square Goodness of Fit Test of the exclusion relationship examines how well observed data are compared with the expected theoretical distribution of an exclusion relationship.

\section{The Mathematical Formula of the Causal Rela-}

\section{tionship $k$}

The mathematical formula of the causal relationship (28-48) $\mathrm{k}$ is defined at every single event, at every single Bernoulli trial $t$, as

$$
\mathrm{k}\left(\mathrm{A}_{\mathrm{t}}, \mathrm{B}_{\mathrm{t}}\right) \equiv \frac{\left(\mathrm{p}\left(\mathrm{A}_{\mathrm{t}} \cap \mathrm{B}_{\mathrm{t}}\right)-\left(\mathrm{p}\left(\mathrm{A}_{\mathrm{t}}\right) \times \mathrm{p}\left(\mathrm{B}_{\mathrm{t}}\right)\right)\right)}{\sqrt[2]{\left(\mathrm{p}\left(\mathrm{A}_{\mathrm{t}}\right) \times \mathrm{p}\left(\underline{\mathrm{A}}_{\mathrm{t}}\right)\right) \times\left(\mathrm{p}\left(\mathrm{B}_{\mathrm{t}}\right) \times \mathrm{p}\left(\underline{B}_{t}\right)\right)}}
$$

where At denotes the cause and Bt denotes the effect. The chi-square distribution can be applied to determine the significance of causal relationship k. Pear-

\begin{tabular}{|c|c|c|c|c|c|c|c|c|c|c|c|c|c|}
\hline Study Id & Year & Country & $\begin{array}{l}\text { Risk } \\
\text { Factor }\end{array}$ & Case_P & Case_T & Con_P & Con_T & k & $p$-val & $\mathrm{X}^{2}(\mathrm{SINE})$ & $\mathrm{X}^{2}(\mathrm{IMP})$ & $\mathrm{X}^{2}(\mathrm{IMP} \wedge \mathrm{SINE})$ & $X^{2}(E X C L)$ \\
\hline $\begin{array}{l}\text { Mousavie- } \\
\text { Jazi et al. }\end{array}$ & 1998 & Sweden & $\begin{array}{l}\text { EBV PCR } \\
\text { DNA }\end{array}$ & 2 & 31 & 0 & 14 & 0.1449318 & 0.46969697 & 26.20 & 0.13 & 26.33 & 1.20 \\
\hline Saal et al. & 1999 & Germany & $\begin{array}{l}\text { EBV PCR } \\
\text { DNA }\end{array}$ & 29 & 84 & 8 & 81 & 0.2954235 & $9.29228 \mathrm{E}-05$ & 35.36 & 1.52 & 36.88 & 31.62 \\
\hline $\begin{array}{l}\text { Takeda } \\
\text { et al. }\end{array}$ & 2000 & Japan & $\begin{array}{l}\text { EBV PCR } \\
\text { DNA }\end{array}$ & 15 & 32 & 0 & 30 & 0.5469937 & 6.07959E-06 & 8.51 & 0.02 & 8.52 & 20.59 \\
\hline Chiu et al. & 2013 & Taiwan & EBV ISH & 23 & 23 & 0 & 13 & 1 & 4.32753E-10 & 0.01 & 0.01 & 0.02 & 44.02 \\
\hline Erre et al. & 2015 & Italy & $\begin{array}{l}\text { EBV PCR } \\
\text { DNA } \\
\text { PBMC }\end{array}$ & 61 & 77 & 33 & 58 & 0.2403144 & 0.00322558 & 3.12 & 11.24 & 14.36 & 86.47 \\
\hline & & & Total & 130 & 247 & 41 & 196 & & & & & & \\
\hline
\end{tabular}
son's (49) concept of correlation (50) is not identical with causation $(28,36,37)$. Causation as such is not identical with correlation. This has been proven many times and is widely discussed in many publications (51).

\section{The 95\% Confidence Interval of the Causal Re- lationship $\boldsymbol{k}$}

A confidence interval (CI) of the causal relationship k calculated from the statistics of the observed

TABLE 6. EBV PCR DNA and ISH studies and RA. 
data can help to estimate the true value of an unknown population parameter with a certain probability. Under some conditions, the $95 \%$ interval for the causal relationship $\mathrm{k}$ is derived (47) as

$$
\left\{\mathrm{k}\left(\mathrm{A}_{\mathrm{t}}, \mathrm{B}_{\mathrm{t}}\right)-\sqrt[2]{\frac{5}{\mathrm{n}}}, \mathrm{k}\left(\mathrm{A}_{\mathrm{t}}, \mathrm{B}_{\mathrm{t}}\right)+\sqrt[2]{\frac{5}{\mathrm{n}}}\right\}
$$

\section{Hypergeometric distribution}

The hypergeometric distribution with its own and very long history $(52,53,54,55)$ is defined by the parameters population size, event count in population, sample size and can be used to calculate the exact probability of an event even for small samples which are drawn from relatively small populations, without replacement.

The hypergeometric distribution differs from the binomial distribution. In contrast to the hypergeometric distribution, the probability of a binomially distributed random variable is the same from trial to trial.

The probability of having exactly at (Table 1) successes or the significance of the causal relationship k can be tested under conditions of sampling without replacement by the hypergeometric distribution (56) as

$$
p\left(a_{t}\right)=\frac{\left(\begin{array}{l}
A_{t} \\
a_{t}
\end{array}\right) \times\left(\begin{array}{l}
N_{t}-A_{t} \\
B_{t}-a_{t}
\end{array}\right)}{\left(\begin{array}{l}
N_{t} \\
B_{t}
\end{array}\right)}
$$

\begin{tabular}{|c|c|c|c|c|}
\hline & & \multicolumn{2}{|l|}{$\mathrm{RA}<\mathrm{B}>$} & \multirow[b]{2}{*}{ Total } \\
\hline & & Yes & No & \\
\hline B19 IgG & Yes & 742 & 504 & 1246 \\
\hline \multirow[t]{2}{*}{$\langle\mathrm{A}\rangle$} & No & 237 & 188 & 425 \\
\hline & Total & 979 & 692 & 1671 \\
\hline & & $k=$ & +0.0335 & \\
\hline & \multicolumn{2}{|c|}{$p$ value $(k)=$} & \multicolumn{2}{|c|}{0.017813306} \\
\hline & \multicolumn{2}{|c|}{$95 \% \mathrm{Cl}(\mathrm{k})=$} & \multicolumn{2}{|c|}{$(-0.0212 ; 0.0882)$} \\
\hline & \multicolumn{2}{|c|}{ WITHOUT $<$ A $>$} & $\mathrm{NO}<\mathrm{B}>$. & \\
\hline & \multicolumn{2}{|c|}{$p($ SINE $)=$} & 0.8582 & \\
\hline & \multicolumn{2}{|c|}{$X^{2}(\operatorname{SINE})=$} & 57.1320 & \\
\hline & \multicolumn{2}{|c|}{ Odds ratio $=$} & 1.1678 & \\
\hline \multicolumn{3}{|c|}{$95 \% \mathrm{Cl}$ (Odds ratio) $=$} & \multicolumn{2}{|c|}{$(0.9350 ; 1.4587)$} \\
\hline & & IF $\langle$ A $>$ & \multicolumn{2}{|c|}{ THEN $<$ B $>$} \\
\hline & & $p(I M P)=$ & 0.6984 & \\
\hline & & $\mathrm{X}^{2}(\mathrm{IMP})=$ & 203.4609 & \\
\hline
\end{tabular}

TABLE 7. The parvovirus B19 Study of Sherina et al., 2017

\begin{tabular}{|c|c|c|c|c|}
\hline & & \multicolumn{2}{|l|}{$\mathrm{RA}<\mathrm{B}>$} & \\
\hline & & Yes & No & Total \\
\hline \multirow{10}{*}{$\begin{array}{l}\text { CMV IgG } \\
<A>\end{array}$} & Yes & 713 & 531 & 1244 \\
\hline & No & 274 & 169 & 443 \\
\hline & Total & 987 & 700 & 1687 \\
\hline & & $k=$ & -0.0405 & \\
\hline & \multicolumn{2}{|c|}{$p$ value $(k)=$} & \multicolumn{2}{|c|}{0.011242387} \\
\hline & \multicolumn{2}{|c|}{$95 \% \mathrm{Cl}(\mathrm{k})=$} & \multicolumn{2}{|c|}{$(-0.0139 ; 0.0950)$} \\
\hline & \multicolumn{2}{|c|}{ WITHOUT $<$ A $>$} & $\mathrm{NO}<\mathrm{B}>$. & \\
\hline & \multicolumn{2}{|c|}{$p(\operatorname{SINE})=$} & 0.8376 & \\
\hline & \multicolumn{2}{|c|}{$X^{2}($ SINE $)=$} & 75.7875 & \\
\hline & \multicolumn{2}{|c|}{ Odds ratio $=$} & 0.8282 & \\
\hline \multicolumn{3}{|c|}{$95 \% \mathrm{Cl}$ (Odds ratio) $=$} & \multicolumn{2}{|c|}{$(0.6632 ; 1.0343)$} \\
\hline & & & \multirow{2}{*}{\multicolumn{2}{|c|}{ THEN <B> }} \\
\hline & & IF $<A>$ & & \\
\hline & & $p(I M P)=$ & 0.6852 & \\
\hline & & $\mathrm{X}^{2}(\mathrm{IMP})=$ & 226.2301 & \\
\hline
\end{tabular}

TABLE 8. The CMV Study of Sherina et al., 2017

\section{Odds Ratio}

The odds ratio (OR) is given $57,58,59$ by

$$
\operatorname{OR}\left(A_{t}, B_{t}\right) \equiv \frac{a_{t} / b_{t}}{c_{t} / d_{t}}=\frac{a_{t} \times d_{t}}{c_{t} \times b_{t}}
$$

It is necessary to point to the case were ct $=0$. Under conditions were $\mathbf{c} t=\mathbf{0}$, there is a conditio sine qua non relationship between At and $\mathrm{Bt}$ while the Odds ratio collapses. To date, it is not generally accepted to divide by zero.

The Odds ratio cannot speak about the natural, profound and far reaching conditio sine qua non relationship but must pass over in silence on this relationship. Pagano \& Gauvreau (60) are quietly returning through the back door to circumvent this fundamental problem of Odds ratio by adding (60) 0.5 to the cells at, bt, ct, dt.

This simple way to circumvent the inconsistency and spectacular methodological incompleteness of Odds ratio is fundamentally misleading. To date, a substantial amount of research is analyzed by the Odds ratio. The more serious difficulty of this point of view is that it appears to be impossible to rely on Odds ratio in principle.

Furthermore, under conditions were $\boldsymbol{b} \boldsymbol{t}=\mathbf{0}, \boldsymbol{a}$ conditio per quam relationship between At and $\mathrm{Bt}$ is given while the Odds ratio collapses again.

For this reason, the Odds ratio is overshadowed by a deep theoretical inconsistency and appears not to be grounded on a seemingly sound piece of reasoning. 
More likely, the Odds ratio (OR) is nothing more but Yule's coefficient of association (6) $1 Q$ re-written (62) in a non-normalized form and given by

$$
\begin{aligned}
& Q\left(A_{t}, B_{t}\right) \equiv \frac{O R\left(A_{t}, B_{t}\right)-1}{O R\left(A_{t}, B_{t}\right)+1} \\
& Q\left(A_{t}, B_{t}\right)=\frac{\frac{\left(a_{t} \times d_{t}\right)}{\left(b_{t} \times c_{t}\right)}-1}{\frac{\left(a_{t} \times d_{t}\right)}{\left(b_{t} \times c_{t}\right)}+1} \\
& Q\left(A_{t}, B_{t}\right)=\frac{\left(a_{t} \times d_{t}\right)-\left(b_{t} \times c_{t}\right)}{\left(b_{t} \times c_{t}\right)} \\
& \frac{\left(a_{t} \times d_{t}\right)+\left(b_{t} \times c_{t}\right)}{\left(b_{t} \times c_{t}\right)} \\
& Q\left(A_{t}, B_{t}\right)=\frac{\left(a_{t} \times d_{t}\right)-\left(b_{t} \times c_{t}\right)}{\left(a_{t} \times d_{t}\right)-\left(b_{t} \times c_{t}\right)}
\end{aligned}
$$

Under conditions where Yule's coefficient of association (Yule, 1900) $Q=0$, there is no association. Although severely and justifiably criticized especially by Karl Pearson (1857-1925), the long-time and rarely challenged leader of statistical science and Heron (63), Odds ratio is still regularly referred to. The standard error and $95 \%$ confidence interval of the Odds ratio (OR) can be calculated according to Altman (64). Given the severely limited character

\begin{tabular}{|c|c|c|c|c|}
\hline & & \multicolumn{2}{|l|}{$\mathrm{RA}<\mathrm{B}>$} & \\
\hline & & Yes & No & Total \\
\hline \multirow{11}{*}{$\begin{array}{l}\text { EBV VCA } \\
\lg ( \\
\langle A\rangle\end{array}$} & Yes & 970 & 679 & 1649 \\
\hline & No & 17 & 21 & 38 \\
\hline & Total & 987 & 700 & 1687 \\
\hline & & $\mathbf{k}=$ & +0.0424 & \\
\hline & \multicolumn{2}{|c|}{$p$ value $(k)=$} & \multicolumn{2}{|c|}{0.029495888} \\
\hline & \multicolumn{2}{|c|}{$95 \% \mathrm{Cl}(\mathrm{k})=$} & \multicolumn{2}{|c|}{$(-0.0120 ; 0.0969)$} \\
\hline & \multicolumn{2}{|c|}{ WITHOUT $<$ A $>$} & $\mathrm{NO}<\mathrm{B}>$. & \\
\hline & \multicolumn{2}{|c|}{$p(\operatorname{SINE})=$} & 0.9899 & \\
\hline & \multicolumn{2}{|c|}{$X^{2}(S I N E)=$} & 0.2758 & \\
\hline & \multicolumn{2}{|c|}{ Odds ratio $=$} & 1.7647 & \\
\hline & \multicolumn{2}{|c|}{$95 \% \mathrm{Cl}$ (Odds ratio) = } & \multicolumn{2}{|c|}{$(0.9241 ; 3.3700)$} \\
\hline
\end{tabular}
of odds ratio, the standard error of the log Odds ratio is calculated as

TABLE 9. The EBV Study of Sherina et al., 2017

$$
\operatorname{SE}\left(\ln \left(\operatorname{OR}\left(\mathrm{A}_{t}, \mathrm{~B}_{\mathrm{t}}\right)\right)\right) \equiv \sqrt[1]{\frac{1}{\mathrm{a}_{\mathrm{t}}}+\frac{1}{\mathrm{~b}_{t}}+\frac{1}{\mathrm{c}_{\mathrm{t}}}+\frac{1}{d_{t}}}
$$

where $\boldsymbol{l n}$ denotes the logarithmus naturalis. The $95 \%$ confidence interval of the odds ratio is given by $95 \% \mathrm{CI}=\exp \left(\ln \left(\mathrm{OR}\left(\mathrm{A}_{\mathrm{t}}, \mathrm{B}_{\mathrm{t}}\right)\right)-\left(1.96 \times \mathrm{SE}\left(\ln \left(\mathrm{OR}\left(\mathrm{A}_{\mathrm{t}}, \mathrm{B}_{\mathrm{t}}\right)\right)\right)\right)\right)$

\begin{tabular}{|c|c|c|c|c|}
\hline & & \multicolumn{2}{|l|}{$\mathrm{RA}<\mathrm{B}>$} & \multirow[b]{2}{*}{ Total } \\
\hline & & Yes & No & \\
\hline \multirow{7}{*}{$\begin{array}{l}\text { EBV PCR } \\
\text { DNA } \\
<A>\end{array}$} & Yes & 29 & 8 & 37 \\
\hline & No & 55 & 73 & 128 \\
\hline & Total & 84 & 81 & 165 \\
\hline & & $\mathbf{k}=$ & +0.2954 & \\
\hline & \multicolumn{2}{|c|}{$p$ value $(k)=$} & \multicolumn{2}{|c|}{$9.29228 \mathrm{E}-05$} \\
\hline & \multicolumn{2}{|c|}{$95 \% \mathrm{Cl}(\mathrm{k})=$} & \multicolumn{2}{|c|}{$(0.1213 ; 0.4695)$} \\
\hline & \multicolumn{2}{|c|}{ Odds ratio $=$} & 4.8114 & \\
\hline \multicolumn{3}{|c|}{$95 \% \mathrm{Cl}$ (Odds ratio) = } & \multicolumn{2}{|c|}{$(2.0413 ; 11.3405)$} \\
\hline & & $\mathrm{IF}<\mathrm{A}>$ & \multicolumn{2}{|c|}{ THEN $<$ B $>$} \\
\hline & & $p(I M P)=$ & 0.9515 & \\
\hline & & $\mathrm{X}^{2}(\mathrm{IMP})=$ & 1.5203 & \\
\hline
\end{tabular}
to

\begin{tabular}{|c|c|c|c|c|}
\hline & & \multicolumn{2}{|l|}{$\mathrm{RA}<\mathrm{B}>$} & \\
\hline & & Yes & No & Total \\
\hline \multirow{9}{*}{$\begin{array}{l}\text { EBV PCR } \\
\text { DNA } \\
<A>\end{array}$} & Yes & 15 & 0 & 15 \\
\hline & No & 17 & 30 & 47 \\
\hline & Total & 32 & 30 & 62 \\
\hline & & $\mathbf{k}=$ & +0.5470 & \\
\hline & \multicolumn{2}{|c|}{$p$ value $(k)=$} & \multicolumn{2}{|c|}{ 6.07959E-06 } \\
\hline & \multicolumn{2}{|c|}{$95 \% \mathrm{Cl}(\mathrm{k})=$} & \multicolumn{2}{|c|}{$(0.2630 ; 0.8310)$} \\
\hline & & $\mathrm{IF}<\mathrm{A}>$ & \multicolumn{2}{|c|}{ THEN $<$ B $>$} \\
\hline & & $p(I M P)=$ & 1.0000 & \\
\hline & & $X^{2}(I M P)=$ & 0.0167 & \\
\hline
\end{tabular}

$\exp \left(\ln \left(\mathrm{OR}\left(\mathrm{A}_{\mathrm{t}}, \mathrm{B}_{\mathrm{t}}\right)\right)+\left(1.96 \times \operatorname{SE}\left(\ln \left(\mathrm{OR}\left(\mathrm{A}_{\mathrm{t}}, \mathrm{B}_{\mathrm{t}}\right)\right)\right)\right)\right)$

TABLE 10. The Study of Saal et al.

TABLE 11. The Study of Takeda et al.

\section{The unknown population proportion pupper}

Tests of hypotheses concerning the sampling distribution of the sample proportion $\mathbf{p}$ (i. e. conditio sine qua non $\mathrm{p}$ (SINE), conditio per quam $\mathrm{p}$ (IMP) et cetera) can be performed using the normal approximation. The calculation of the rejection region based on the sample proportion to construct a confidence interval for an unknown $(65,66)$ population propor- 
tion pupper can be performed under conditions of sampling without replacement by the formula

$$
\pi_{\text {eritical upper }}=\left(\mathrm{p}-\frac{1}{2 \times \mathrm{n}}\right)-\left(\mathrm{Z} \times \sqrt[2]{\left(\frac{\mathrm{p} \times(1-\mathrm{p})}{\mathrm{n}}\right) \times\left(\frac{\mathrm{N}-\mathrm{n}}{\mathrm{N}-1}\right)}\right)
$$

while the term $((\mathrm{N}-\mathrm{n}) /(\mathrm{N}-1))$ denotes the finite population correction (67).

TABLE 12. The Study of Chiu et al.

\begin{tabular}{|c|c|c|c|c|}
\hline & & \multicolumn{2}{|l|}{$\mathrm{RA}<\mathrm{B}>$} & \\
\hline & & Yes & No & Total \\
\hline \multirow{3}{*}{$\begin{array}{l}\text { EBV ISH } \\
<A>\end{array}$} & Yes & 23 & 0 & 23 \\
\hline & No & 0 & 13 & 13 \\
\hline & Total & 23 & 13 & 36 \\
\hline & & $k=$ & +1.0000 & \\
\hline & \multicolumn{2}{|c|}{$p$ value $(k)=$} & \multicolumn{2}{|l|}{ 4.32753E-10 } \\
\hline & \multicolumn{2}{|c|}{ WITHOUT $<$ A $>$} & $\mathrm{NO}<\mathrm{B}>$. & \\
\hline & & $p(\operatorname{SINE})=$ & 1.0000 & \\
\hline & \multicolumn{2}{|c|}{$\mathrm{X}^{2}(\mathrm{SINE})=$} & 0.0109 & \\
\hline & & $\mid F<A>$ & \multicolumn{2}{|l|}{ THEN $<$ B $>$} \\
\hline & & $p(\mathrm{IMP})=$ & 1.0000 & \\
\hline & & $X^{2}(\mathrm{IMP})=$ & 0.0109 & \\
\hline & \multicolumn{2}{|c|}{$<A>$ is SINE } & \multicolumn{2}{|l|}{ and IMP of $<\mathrm{B}>$} \\
\hline & \multicolumn{2}{|c|}{$p(S I N E \wedge \mid M P)=$} & 1.0000 & \\
\hline & \multicolumn{2}{|c|}{$\mathrm{X}^{2}(\mathrm{SINE} \wedge \mathrm{IMP})=$} & 0.0217 & \\
\hline
\end{tabular}

\section{The Chi Square Distribution}

The following critical values $(65,66)$ of the chi square distribution (68) as visualized by Table 13 are used in this publication.

TABLE 13. The critical values of the chi square distribution (degrees of freedom: 1)

\begin{tabular}{|l|l|l|l|}
\hline & $\mathbf{p}$-Value & One sided $\mathbf{X}^{\mathbf{2}}$ & Two sided $\mathbf{X}^{\mathbf{2}}$ \\
\hline & 0.1000000000 & 1.642374415 & 2.705543454 \\
& $\mathbf{0 . 0 5 0 0 0 0 0 0 0 0}$ & $\mathbf{2 . 7 0 5 5 4 3 4 5 4}$ & $\mathbf{3 . 8 4 1 4 5 8 8 2 1}$ \\
& 0.0400000000 & 3.06490172 & 4.217884588 \\
& 0.0300000000 & 3.537384596 & 4.709292247 \\
& 0.0200000000 & 4.217884588 & 5.411894431 \\
The chi square & 0.0100000000 & 5.411894431 & 6.634896601 \\
distribution & 0.0010000000 & 9.549535706 & 10.82756617 \\
& 0.0001000000 & 13.83108362 & 15.13670523 \\
& 0.0000100000 & 18.18929348 & 19.51142096 \\
& 0.0000010000 & 22.59504266 & 23.92812698 \\
& 0.0000001000 & 27.03311129 & 28.37398736 \\
& 0.0000000100 & 31.49455797 & 32.84125335 \\
& 0.0000000010 & 35.97368894 & 37.32489311 \\
& 0.0000000001 & 40.46665791 & 41.82145620 \\
\hline
\end{tabular}

\section{The rule of three}

The Chi-square goodness of fit test (68) used to test whether a sample distribution is identical with a theoretical distribution yields only an approximate $\mathrm{p}$-value and works when the dataset analyzed is large enough ( $\mathrm{n} \sim 30$ and more). An approximate and conservative (one sided) confidence interval as discussed by Rumke (69), Louis (70), Hanley et al. (71) and Jovanovic \& Levy (72) and known as the rule of three can be used if the Chi-square goodness of fit test (with a continuity correction) (73) cannot be applied.

\section{RESULTS}

Rheumatoid arthritis is an inflammatory progressive disease with more or less a very poor prognosis. In this context, the studies (74-99) considered for a re-analysis should help us to get a better understanding of this disease.

\section{Without EBV IgG antibody positivity no rheu- matoid arthritis}

EBV VCA IgG antibodies can be used to investigate the relationship between EBV and RA.

\section{Claims}

\section{Null hypothesis: (no causal relationship)}

The presence of EBV VCA IgG antibodies is a necessary condition (a conditio sine qua non) of rheumatoid arthritis. In other words, the sample distribution agrees with the hypothetical (theoretical) distribution of a necessary condition.

\section{Alternative hypothesis: (causal relationship)}

The presence of EBV VCA IgG antibodies is not a necessary condition (a conditio sine qua non) of rheumatoid arthritis. In other words, the sample distribution does not agree with the hypothetical (theoretical) distribution of a necessary condition. The significance level (Alpha) below which the null hypothesis will be rejected is alpha $=0.05$.

\section{Proof}

The data reviewed by this article which investigated the relationship between EBV VCA IgG antibodies and rheumatoid arthritis are presented by Table 2. In total, 9 studies with 2507 cases and controls provided non self-contradictory data and were meta-analysed while the level of significance was alpha $=0.05$. In particular, all studies provided significant evidence of a conditio sine qua non relationship between EBV VCA IgG antibodies and rheumatoid arthritis ( $\mathrm{X}^{2}$ (Calculated [conditio sine qua non]) $=0.8597$ and is less than $\mathrm{X}^{2}$ (Critical [conditio sine 
qua non]) =16.919). In fact, the presence of EBV VCA IgG antibodies is a necessary condition (a conditio sine qua non) of rheumatoid arthritis. Ultimately, for this reason, without the presence of EBV VCA IgG antibodies no rheumatoid arthritis.

\section{Q.e.d.}

\section{Without EBV EBNA IgG antibody positivity no rheumatoid arthritis}

\section{Claims}

\section{Null hypothesis}

The presence of EBV EBNA IgG antibodies is a necessary condition (a conditio sine qua non) of rheumatoid arthritis. In other words, the sample distribution agrees with the hypothetical (theoretical) distribution of a necessary condition.

\section{Alternative hypothesis}

The presence of EBV EBNA IgG antibodies is not a necessary condition (a conditio sine qua non) of rheumatoid arthritis. In other words, the sample distribution does not agree with the hypothetical (theoretical) distribution of a necessary condition.

The significance level (Alpha) below which the null hypothesis will be rejected is alpha $=0.05$.

\section{Proof}

The data reviewed by this article which investigated the relationship between EBV EBNA IgG antibodies and rheumatoid arthritis are shown in Table 3. At this point it might be important that 7 studies with 794 cases and controls provided non self-contradictory data and were considered for a meta-analysis while the level of significance was alpha $=0.05$. We can point to the fact that all 7 studies (Table 4) provided significant evidence of a conditio sine qua non relationship between EBV EBNA IgG antibodies and rheumatoid arthritis $\left(\mathrm{X}^{2}\right.$ (Calculated [conditio sine qua non]) $=3.1435$ and is less than $\mathrm{X}^{2}$ (Critical [conditio sine qua non]) $=14.0671$ ). By that very fact, the presence of EBV EBNA IgG antibodies is a necessary condition (a conditio sine qua non) of rheumatoid arthritis. The last point suggests that without the presence of EBV EBNA IgG antibodies no rheumatoid arthritis.

Q.e.d.

\section{EBV is a cause of rheumatoid arthritis}

(The Study of Saal et al. (Table 10))

The presence of EBV DNA in synovial tissues is a possible method to show an etiological link be- tween EBV and the pathogenesis of rheumatoid arthritis. Several studies published convincing results on this topic.

\section{Claims}

\section{Null hypothesis: (no causal relationship)}

There is no significant causal relationship between an infection by Epstein-Barr virus and rheumatoid arthritis. $(\mathrm{k}=0)$.

\section{Alternative hypothesis: (causal relationship)}

There is a significant causal relationship between an infection by Epstein-Barr virus and rheumatoid arthritis. $\left(\mathrm{k}^{1} 0\right)$.

Conditions. Alpha level $=5 \%$.

The two tailed critical Chi square value (degrees of freedom $=1$ ) for alpha level $5 \%$ is 3.841458821 .

\section{Proof}

The data for this hypothesis test were provided by Saal et al. (Table 10) and are illustrated by the Table 10. The causal relationship k(Epstein-Barr virus, rheumatoid arthritis) was calculated as $\mathrm{k}=$ $+0.2954(\mathrm{p}$ value $(\mathrm{k})=9.29228 \mathrm{E}-05 ; 95 \% \mathrm{CI}(\mathrm{k})=$ $[0.1213 ; 0.4695])$ while the level of significance was alpha $=0.05$. The data of Saal et al. (Table 10) provide evidence that EBV is a sufficient condition $\left(\mathrm{X}^{2}(\mathrm{IMP})=1.5203 ; \mathrm{X}^{2}\right.$ Critical $\left.(\mathrm{IMP})=3.841458821\right)$ of rheumatoid arthritis while the cause effect relationship between EBV and RA is highly significant $(\mathrm{k}=+0.2954(\mathrm{p}$ value $(\mathrm{k})=9.29228 \mathrm{E}-05)$.

\section{Q.e.d.}

\section{EBV is a cause of rheumatoid arthritis}

(The Study of Takeda et al. (Table 11))

\section{Claims}

\section{Null hypothesis: (no causal relationship)}

There is no significant causal relationship between an infection by Epstein-Barr virus and rheumatoid arthritis. $(\mathrm{k}=0)$.

\section{Alternative hypothesis: (causal relationship)}

There is a significant causal relationship between an infection by Epstein-Barr virus and rheumatoid arthritis. $\left(\mathrm{k}^{1} 0\right)$.

Conditions. Alpha level $=5 \%$.

The two tailed critical Chi square value (degrees of freedom =1) for alpha level $5 \%$ is 3.841458821 .

\section{Proof}

The data for this hypothesis test were provided by Study of Takeda et al. (Table 11) and are illustrat- 
ed by the Table 11 . The causal relationship k(Epstein-Barr virus, rheumatoid arthritis) was calculated as $\mathrm{k}=+0.5470(\mathrm{p}$ value $(\mathrm{k})=6.07959 \mathrm{E}-06 ; 95 \% \mathrm{CI}$ $(\mathrm{k})=[0.2630 ; 0.8310])$ while the level of significance was alpha $=0.05$. The data of Takeda et al. (Table 11) provide evidence that EBV is a sufficient condition $\left(\mathrm{X}^{2}(\mathrm{IMP})=0.0167 ; \mathrm{X}^{2}\right.$ Critical $(\mathrm{IMP})=$ 3.841458821) of rheumatoid arthritis while the cause effect relationship between EBV and RA is highly significant $(\mathrm{k}=+0.5470(\mathrm{p}$ value $(\mathrm{k})=6.07959 \mathrm{E}$ 06).

\section{Q.e.d.}

\section{$E B V$ is the cause of rheumatoid arthritis}

The Study of Chiu et al. (Table 12)

\section{Claims}

\section{Null hypothesis: (no causal relationship)}

There is no significant causal relationship between an infection by Epstein-Barr virus and rheumatoid arthritis. $(\mathrm{k}=0)$.

\section{Alternative hypothesis: (causal relationship)}

There is a significant causal relationship between an infection by Epstein-Barr virus and rheumatoid arthritis. $\left(\mathrm{k}^{1} 0\right)$.

Conditions. Alpha level = 5\%.

The two tailed critical Chi square value (degrees of freedom $=1$ ) for alpha level $5 \%$ is 3.841458821 .

\section{Proof}

The data for this hypothesis test were provided by Study of Chiu et al. (Table 12) and are illustrated by the Table 12. The causal relationship k(Epstein-Barr virus, rheumatoid arthritis) was calculated as $\mathrm{k}=+1.0$ ( $\mathrm{p}$ value $(\mathrm{k})=4.32753 \mathrm{E}-10)$ while the level of significance was alpha $=0.05$. The data of Study of Chiu et al. (Table 12) provide evidence that EBV is a necessary $\left(\mathrm{X}^{2}(\mathrm{SINE})=0.0109 ; \mathrm{X}^{2}\right.$ Critical $(\mathrm{SINE})=3.841458821)$, a sufficient $\left(\mathrm{X}^{2}(\mathrm{IMP})=\right.$ $0.0109 ; X^{2}$ Critical (IMP) $=3.841458821$ ) and equally a necessary and sufficient condition $\left(\mathrm{X}^{2}(\mathrm{SINE}\right.$ and IMP $)=0.0217 ; \mathrm{X}^{2}$ Critical (SINE and $\mathrm{IMP})=3.841458821$ ) of rheumatoid arthritis while the cause effect relationship is highly significant $(\mathrm{k}=$ +1.0 ; $\mathrm{p}$ value $(\mathrm{k})=4.32753 \mathrm{E}-10)$. Epstein-Barr virus is the cause of rheumatoid arthritis $(\mathrm{k}=+1.0$; $\mathrm{p}$ value $(\mathrm{k})=4.32753 \mathrm{E}-10)$.

Q.e.d.

\section{DISCUSSION}

Epstein-Barr Virus discovered 1964 by Epstein et al. (100) is a widely disseminated lymphotropic herpes virus. As key results, several studies suspected that particularly Epstein-Barr virus is involved in etiology of rheumatoid arthritis. Catalano et al. (21) reported that patients with RA had a significantly higher frequency and titer of rheumatoid arthritis-associated nuclear antigen (anti-RANA) antibodies than did control subjects and confirmed the previous results of Alspaugh and Tan (18). Using the protein blot technique, Billings et al. (23) were able to provide evidence that rheumatoid arthritis nuclear antigen (RANA) and Epstein-Barr virus nuclear antigen identify the same polypeptide.

However, data about EBV burden in RA patients reported have been contradictory and the role of EBV still remains elusive. Indeed, on this matter, as with so many other major medical issues, several reviews101, 102 and meta-analysis were not able to find a definite solution on this fundamental topic. Thus far, it is not excluded that this meta-analyses is susceptible to different kind of publication bias. In its broadest sense, the studies analysed differ in various aspect. Thus, the question arises why not all patients were diagnosed according to the American Rheumatism Association 1987 revised criteria for the classification 103 of RA. While some studies considered for a meta-analysis provided no diagnostic criteria for the diagnosis of rheumatoid arthritis other studies utilised a form of the American College of Rheumatology (ACR) or American Rheumatology Association criteria. Additionally, reporting of data of some studies are to some extent unsatisfactory, because not all studies provided detailed cut-off values for EBV sero-positivity. RA patients and nonRA controls both were tested quantitatively for different antibodies against Epstein-Barr virus while using different substrates or kits or antigens and various technologies. Hence we need to take into consideration under what conditions is it appropriate to use antibodies against Epstein-Barr virus to investigate the relationship between EBV and rheumatoid arthritis? To date it is known that IgG molecules with two antigen binding sites are created and released by human plasma B cells not without any reason but i. e. to control an infection in human body. Especially IgM, IgG et cetera molecules are not existing for ever but suffer a kind of pharmacokinetics. The half-live (104) for total IgG was found to be 
25.8 days. In this context EBV antibodies are major components of human humoral immunity allowing controlling an EBV infection of human body tissues through several mechanisms. A natural concern is whether EBV antibodies suffer a turnover rate with regard to the infectious status. Several factors can influence the pharmacokinetics of EBV antibodies. The half-lives for antibodies specific for Epstein-Barr virus antigens depend on EBV infection status. In the case of recent EBV infection or during the course of EBV reactivation the humoral response of human immune system against EBV antigens will lead to different changes in antibodies specific for Epstein-Barr virus antigens. An acute EBV (re-) infection is indicated by the presence of VCA IgM and VCA IgG but without EBNA-1 IgG. Typical for a past EBV infection is the presence of VCA IgG and EBNA-1 IgG but without VCA IgM (105).

At the very least, enough is published to convince our self that after a primary EBV infection, EBV persists for life in vivo in a quiescent state in resting human memory B cells (106) which circulate in the peripheral blood. This fact considerably leads to the conclusion that VCA IgG or EBNA IgG provide evidence of an EBV infection of human body and are therefore helpful in causal analysis. And yet, despite contradictory results several studies give convincing evidence of the linkage between EBV and RA. Many studies demonstrated remarkable higher levels of different serum antibodies against Epstein-Barr virus in patients suffering from rheumatoid arthritis than in healthy controls $(21,22,24,76,107,108$, 109). Baecklund et al. (110) provided evidence that a high inflammatory activity of RA rather than the treatment of RA is a major risk determinant of lymphoma in a subset of patients with RA.

Sherina et al. (99) conducted the largest epidemiological study to date and investigated the prevalence of EBV, human cytomegalovirus (CMV) and parvovirus B19 antibodies by ELISA in serum samples from 990 RA patients and 700 controls. The prevalence of EBV IgG was $98.3 \%$ in patients with RA and $97.0 \%$ in controls. Parvovirus B19 IgG were detected in $75.8 \%$ of patients with RA and in $72.8 \%$ of healthy controls. CMV IgG was documented in $75.9 \%$ of controls and in $72.2 \%$ of patients with RA. For the first time, the viruses EBV, CMV and parvovirus B19 have been examined by Sherina et al. (99) in the context of a very large and impressive epidemiological study in patients with RA and in non-RA subjects. Sherina et al. used the presence of anti-viral antibodies as surrogate markers for viral infection.
The data of Sherina et al. (99) with a sample size of $n=1690$ cases and controls concerning the relationship between parvovirus $B 19$ and rheumatoid arthritis (Table 7) were not self-contradictory and could be used for further analysis. The data of Sherina et al. (99) do not support the Null-hypothesis: without parvovirus B19 infection no rheumatoid arthritis $\left(\mathrm{X}^{2}\right.$ (SINE) Calculated $=57.9396$ and thus far greater than $\mathrm{X}^{2}(\mathrm{SINE})$ Critical $\left.=3.841458821\right)$. The data of Sherina et al. (99) do not support the Null-hypothesis: if parvovirus B19 infection then rheumatoid arthritis ( $\mathrm{X}^{2}$ (IMP) Calculated $=205.3791$ and thus far greater than $\mathrm{X}^{2}$ (IMP) Critical = 3.841458821). In other words, according to the data of Sherina et al. (99) parvovirus B19 is neither a cause nor the cause of rheumatoid arthritis (Table 7) even if statistically not independent (111) of each other.

Contradicting the study Sherina et al. (99), Takahashi (112) et al., 1998 found Human parvovirus B19 DNA (B19) in the synovium of 30/39 RA patients in contrast to $9 / 57$ controls while neither the study of Kerr (113) et al. nor the study of Naciute (114) et al. with B19 DNA in 30/118 of RA patients vs. 9/49 in healthy controls confirmed the data of Takahashi (112) et al., 1998.

The data of Sherina et al. (99) concerning the relationship between $C M V$ and rheumatoid arthritis were not self-contradictory (Table 8 ) and could be considered for further analysis. The data of Sherina et al. (99) do not support the Null-hypothesis: without $C M V$ infection no rheumatoid arthritis ( $p$ (SINE) $=0.8376 ; \mathrm{X}^{2}(\mathrm{SINE})$ Calculated $=75.7875$ and thus far greater than $\mathrm{X}^{2}$ (SINE) Critical $=3.841458821$ ). The data of Sherina et al. (99) do not support the Null-hypothesis: if CMV infection then rheumatoid arthritis $\quad\left(\mathrm{p}(\mathrm{IMP})=0.6852 ; \quad \mathrm{X}^{2}(\mathrm{IMP}) \quad\right.$ Calculated $=226.2301$ and thus far greater than $\mathrm{X}^{2}$ (IMP) Criti$c a l=3.841458821)$. Thus far, according to the data of Sherina et al. (99) it appears not to be highly probable that CMV might somehow be involved in the pathogenesis of RA. CMV is neither a cause nor the cause (Table 8) of RA ( $\mathrm{k}=-0.0405$; p value $(\mathrm{k})$ $=0.011242387$ ). The data of Sherina et al. (99) concerning the relationship between EBV VCA IgG and rheumatoid arthritis were not self-contradictory (Table 9) and were used for further analysis. The data of Sherina et al. (99) do support the Null-hypothesis: without EBV infection (documented by EBV VCA IgG antibodies) no rheumatoid arthritis (p ( SINE) $=0.9899 ; \mathrm{X}^{2}$ (SINE) Calculated $=0.2750$ and is thus far not greater than $\mathrm{X}^{2}(\mathrm{SINE})$ Critical $=3.841458821$, 
$\mathrm{k}>0$; $\mathrm{p}$ value $(\mathrm{k})=0.029020429)$. This Null-hypothesis is supported by other studies too. In other words, according to the data (Table 9) of the very large epidemiological study conducted by Sherina et al. (99) EBV infection is the cause of rheumatoid arthritis.

However, even EBV DNA analysis provided view contradictory results; while some studies failed to detect EBV DNA in RA patients (115) other studies were successful. Saal et al. (88) (Table 10) investigated the presence of the Epstein-Barr virus (EBV) in rheumatoid arthritis (RA) synovium and concluded that EBV is an environmental risk factor for RA. According to the study of Saal et al. (88) there is a highly significant cause effect relationship (Table 10) between an EBV infection of human joints and RA $(\mathrm{k}=+0.2954 ; \mathrm{p}$ value $(\mathrm{k})=9.29228 \mathrm{E}-05)$ while the conditio per quam relationship between EBV and RA is significant. In other words, if EBV infection of human joints then RA ( $p($ IMP $)=0.9515 ; X^{2}$ $(\mathrm{IMP})=1.5203)$.

Takeda et al. (91) (Table 11) detected the existence of EBV DNA by PCR in the synovial tissue in 15 of the 32 samples from the RA patients (47\%), but not in any of the 30 osteoarthritis patients (Table 11). Takeda et al. (91) were able to provide evidence that an infection of human joints by EBV is a conditio per quam of rheumatoid arthritis. In other words, according to the study of Takeda et al. (91) (Table 11) if infection of human joints by EBV then RA ( $p$ $($ IMP $)=1 ; X^{2}($ IMP $\left.)=0.0167\right)$. The same study of Takeda et al. (91) (Takeda et al., 2000) provided evidence of a highly significant cause effect relationship between an infection of human joints by EBV and RA $(\mathrm{k}=+0.5470 ; \mathrm{p}$ value $(\mathrm{k})=6.07959 \mathrm{E}-06)$.

Using real-time polymerase chain reaction Balandraud et al. (116) were able to document that Epstein-Barr virus DNA load in the peripheral blood (116) of patients with rheumatoid arthritis was increased almost 10 -fold .

\section{In-situ hybridization}

In-situ hybridization (ISH), has been described in the year 1969 by Joseph G. Gall (117). According to Fan \& Gulley (118), In situ hybridization (ISH) to Epstein-Barr virus (EBV)-encoded RNA (EBER) is an appropriate method to detect and localize EBV DNA in biopsy samples of rheumatoid arthritis patients and healthy controls. Like any other method, even the in situ hybridization is not completely free of bias and can be labelled with some severe limita- tions. The study group of Chiu et al. (96) (Table 12) conducted a study to investigate the expression of Epstein-Barr virus-encoded small RNA1 (EBER1) by ISH in the synovial tissues taken from 23 patients with rheumatoid arthritis and 13 patients with OA. The RA patients were diagnosed according to the American Rheumatism Association 1987 revised criteria for the classification of rheumatoid arthritis (103). All synovial samples from RA showed positive expression of EBER1 (23/23,100\%), but none of the control group patients $(0 / 13)$.

According to the study of Chiu et al. (96) (Table 12), an EBV virus infection is a necessary condition $\left(\mathrm{p}(\mathrm{SINE})=1 ; \mathrm{X}^{2}(\mathrm{SINE})=0.0109\right)$, an EBV virus infection is a sufficient condition ( $\mathrm{p}$ (IMP) $=1 ; \mathrm{X}^{2}$ $(\mathrm{IMP})=0.0109)$ and an EBV virus infection is a necessary and sufficient condition ( $\mathrm{p}$ (SINE AND IMP) $=1 ; \mathrm{X}^{2}(\mathrm{SINE}$ AND IMP $\left.)=0.0217\right)$ of rheumatoid arthritis while the cause effect relationship (Table 12) between an EBV infection and RA is highly significant $(\mathrm{k}=+1$; $\mathrm{p}$ value $(\mathrm{k})=4.32753 \mathrm{E}-10)$.

Mehraein et al. (119) investigated the influence of synovial virus infections in rheumatoid arthritis, and found evidence of increased synovial persistence of EBV in 5/29 rheumatoid arthritis (RA) patients.

Mahabadi et al. (98) investigated Epstein-Barr virus DNA by PCR in synovial fluid of 50 rheumatoid arthritis patients and detected EBV DNA by PCR in 30 cases (60\%). Mahabadi et al. (98) concluded that EBV may play a role in the pathogenesis of RA.A control group was not provided and it was not possible to consider the data for causal analysis.

Although it has been investigated and speculated for over 40 years that Epstein-Barr virus is a strong candidate to contribute to the cause of RA definite evidence was wanting. Considering the half-life (120) of EBV antibodies and the results of the reviews (121) mentioned, the studies re-analysed in the present article indicate a high degree of confidence that an EBV infection is the cause RA and the etiology of rheumatoid arthritis no longer remains unknown. The lack of appropriate ancient medical texts regarding rheumatoid arthritis has forced many researchers to acknowledge the first description of RA by modern medicine to Augustin Jacob Landré-Beauvais $(122,123)$ from the year 1800 published in his dissertation. In the year 2018 and about 218 years later, the cause of rheumatoid arthritis is finally identified. 


\section{CONCLUSION}

The results of the present study are consistent with the hypothesis that there is a relationship between EBV and RA and give further evidence of the linkage between EBV and RA. The data not only do support the hypothesis that EBV infection is some-

\section{REFERENCES}

1. Miossec $P$ \& van den Berg $W$. Th1/Th2 cytokine balance in arthritis. Arthritis and rheumatism. $1997 ; 40(12): 2105-2115$. https://doi.org/10.1002/1529-0131(199712)40:12\&lt;2105:AIDART2\&gt;3.0.CO;2-B https://www.ncbi.nlm.nih.gov/ pubmed/9416846

2. Gabriel SE, Crowson CS \& O'Fallon WM. The epidemiology of rheumatoid arthritis in Rochester, Minnesota, 1955-1985. Arthritis and rheumatism. 1999 ; 42(3): 415-420. https://doi. org/10.1002/1529-0131(199904)42:3<415:AID-ANR4>3.0.CO;2-Z https://www.ncbi.nlm.nih.gov/pubmed/10088762

3. Linos A, Kaklamani VG, Kaklamani E, Koumantaki Y, Giziaki E, Papazoglou S \& Mantzoros CS. Dietary factors in relation to rheumatoid arthritis: a role for olive oil and cooked vegetables? The American journal of clinical nutrition. 1999 ; 70(6): 1077-1082. https://doi.org/10.1093/ajcn/70.6.1077 https://www.ncbi.nlm.nih. gov/pubmed/10584053

4. Symmons DP, Barrett EM, Bankhead CR, Scott DG \& Silman AJ. The incidence of rheumatoid arthritis in the United Kingdom: results from the Norfolk Arthritis Register. British journal of rheumatology. 1994 ; 33(8): 735-739. https://www.ncbi.nlm.nih.gov/ pubmed/8055200

5. Pincus T \& Callahan LF. Taking mortality in rheumatoid arthritis seriously--predictive markers, socioeconomic status and comorbidity. The Journal of rheumatology. 1986 ; 13(5): 841-845. https://www.ncbi.nlm.nih.gov/pubmed/3820193

6. Mclntosh E. The cost of rheumatoid arthritis. British journal of rheumatology. 1996 ; 35(8): 781-790. https://www.ncbi.nlm.nih.gov/ pubmed/8761194

7. Yelin E \& Wanke LA. An assessment of the annual and long-term direct costs of rheumatoid arthritis: the impact of poor function and functional decline. Arthritis and rheumatism. $1999 ; 42(6)$ : 1209 1218. https://doi.org/10.1002/1529-0131(199906)42:6<1209:AIDANR18>3.0.CO;2-M https://www.ncbi.nlm.nih.gov/ pubmed/10366114

8. Jaswal S, Mehta HC, Sood AK \& Kaur J. Antioxidant status in rheumatoid arthritis and role of antioxidant therapy. Clinica chimica acta; international journal of clinical chemistry. 2003 ; 338(1-2): 123-129. https://www.ncbi.nlm.nih.gov/pubmed/14637276

9. Grant WB. The role of meat in the expression of rheumatoid arthritis. The British journal of nutrition. $2000 ; 84(5): 589-595$. https://www.ncbi.nlm.nih.gov/pubmed/11177171

10. Shapiro JA, Koepsell TD, Voigt LF, Dugowson CE, Kestin M \& Nelson JL. Diet and rheumatoid arthritis in women: a possible protective effect of fish consumption. Epidemiology (Cambridge, Mass.). 1996 ; 7(3): 256-263. https://www.ncbi.nlm.nih.gov/ pubmed/8728438

11. Linos A, Worthington JW, O'Fallon WM \& Kurland LT. The epidemiology of rheumatoid arthritis in Rochester, Minnesota: a study of incidence, prevalence, and mortality. American journal of epidemiology. 1980 ; 111(1): 87-98. https://www.ncbi.nlm.nih.gov/ pubmed/7352462

12. Karlson EW, Mandl LA, Hankinson SE \& Grodstein F. Do breast-feeding and other reproductive factors influence future risk of rheumatoid arthritis? Results from the Nurses' Health Study. Arthritis and rheumatism. 2004 ; 50(11): 3458-3467. https://doi.org/10.1002/art.20621. https://www.ncbi.nlm.nih.gov/ pubmed/15529351

13. Stolt P, Bengtsson C, Nordmark B, Lindblad S, Lundberg I, Klareskog $L$ \& Alfredsson L. Quantification of the influence of how involved in the pathogenesis of RA but demand us to accept that EBV is the cause of $\mathrm{RA}(\mathrm{k}=+1.0000$; $\mathrm{p}$ value $(\mathrm{k})=4.32753 \mathrm{E}-10)$.

Copyright $(2018$ Ilija Barukčić. This is an open access article distributed under the Creative Commons Attribution License, which permits unrestricted use, distribution, and reproduction in any medium, provided the original work is properly cited.

Conflict of interest: none declared Financial support: none declared

cigarette smoking on rheumatoid arthritis: results from a population based case-control study, using incident cases. Annals of the rheumatic diseases. 2003; 62(9): 835-841. https://www.ncbi.nlm. nih.gov/pubmed/12922955

14. Meyer O. Parvovirus B19 and autoimmune diseases. Joint, bone, spine revue du rhumatisme. $2003 ; 70(1): 6-11$. https://www.ncbi. nlm.nih.gov/pubmed/12639611

15. Cooke SP, Rigby SP, Griffiths DJ \& Venables PJ. Viral studies in rheumatic disease. Annales de medecine interne. 1998 ; 149(1): 30-33. https://www.ncbi.nlm.nih.gov/pubmed/11490514 .

16. Griffiths DJ. Rheumatoid arthritis: a viral aetiology? Hospital medicine (London, England 1998). 2000 ; 61(6): 378-379. https:// www.ncbi.nlm.nih.gov/pubmed/10962648

17. Tzellos S \& Farrell PJ. Epstein-barr virus sequence variationbiology and disease. Pathogens (Basel, Switzerland). 2012 ; 1(2): 156-174. https://doi.org/10.3390/pathogens1020156 https://www. ncbi.nlm.nih.gov/pubmed/25436768

18. Alspaugh MA \& Tan EM. Serum antibody in rheumatoid arthritis reactive with a cell-associated antigen. Demonstration by precipitation and immunofluorescence. Arthritis and rheumatism. 1976 ; 19(4): 711-719. https://www.ncbi.nlm.nih.gov/ pubmed/1085148

19. Alspaugh MA, Jensen FC, Rabin H \& Tan EM. Lymphocytes transformed by Epstein-Barr virus. Induction of nuclear antigen reactive with antibody in rheumatoid arthritis. The Journal of experimental medicine. 1978 ; 147(4): 1018-1027. https://www. ncbi.nlm.nih.gov/pubmed/206643

20. Kosaka S. Detection of antibody to a new antigen induced by Epstein-Barr virus in rheumatoid arthritis. The Tohoku journal of experimental medicine. $1979 ; 127(2): 157-160$. https://www.ncbi. nlm.nih.gov/pubmed/216133

21. Catalano MA, Carson DA, Slovin SF, Richman DD \& Vaughan JH. Antibodies to Epstein-Barr virus-determined antigens in normal subjects and in patients with seropositive rheumatoid arthritis. Proceedings of the National Academy of Sciences of the United States of America. 1979 ; 76(11): 5825-5828. https://www.ncbi.nlm. nih.gov/pubmed/230491

22. Alspaugh MA, Henle G, Lennette ET \& Henle W. Elevated levels of antibodies to Epstein-Barr virus antigens in sera and synovial fluids of patients with rheumatoid arthritis. The Journal of clinical investigation. 1981 ; 67(4): 1134-1140. https://www.ncbi.nlm.nih. gov/pubmed/6259211

23. Billings PB, Hoch SO, White PJ, Carson DA \& Vaughan JH. Antibodies to the Epstein-Barr virus nuclear antigen and to rheumatoid arthritis nuclear antigen identify the same polypeptide. Proceedings of the National Academy of Sciences of the United States of America. 1983 ; 80(23): 7104-7108. https://www.ncbi.nlm. nih.gov/pubmed/6316343

24. Shimizu N, Yamaki M, Sakuma S, Ono Y \& Takada K. Three Epstein-Barr virus (EBV)-determined nuclear antigens induced by the BamHI E region of EBV DNA. International journal of cancer. 1988 ; 41(5): 744-751. https://www.ncbi.nlm.nih.gov/ pubmed/2835324

25. Simon LS. DMARDs in the treatment of rheumatoid arthritis: current agents and future developments. International journal of clinical practice. 2000 ; 54(4): 243-249. https://www.ncbi.nlm.nih.gov/ pubmed/10912314

26. Moher D, Liberati A, Tetzlaff J \& Altman DG. Preferred reporting items for systematic reviews and meta-analyses: the PRISMA 
statement. Annals of internal medicine. 2009 ; 151(4): 264-9, W64. https://www.ncbi.nlm.nih.gov/pubmed/19622511

27. Liberati A, Altman DG, Tetzlaff J, Mulrow C, Gøtzsche PC, loannidis JPA, Clarke M, Devereaux PJ, Kleijnen J \& Moher D. The PRISMA statement for reporting systematic reviews and meta-analyses of studies that evaluate health care interventions: explanation and elaboration. PLoS medicine. 2009 ; 6(7): e1000100. https://doi. org/10.1371/journal.pmed.1000100 https://www.ncbi.nlm.nih.gov/ pubmed/19621070

28. Barukčić I. Die Kausalität, edn 1. Hamburg: Wiss.-Verl., 1989

29. Barukčić I. Die Kausalität, edn 2. Wilhelmshaven: Scientia, 1997.

30. Barukčić I. Causality: New statistical methods. Norderstedt, Germany: Books on Demand $\mathrm{GmbH}, 2005$.

31. Barukčić I. Causality: New statistical methods, edn 2. Norderstedt: Books on Demand, 2006a.

32. Barukčić I. New Method for Calculating Causal Relationships. XXIIIrd International Biometric Conference, Montréal, Québec, Canada, July 16 - 21, 2006. 2006a ; 23): 49.

33. Barukčić I. Causality I. A theory of energy, time and space, edn 5 , 2009a.

34. Barukčić I. Causality II. A theory of energy, time and space, edn 5, 2009b.

35. Barukčić I. The deterministic relationship between cause and effect. XXVIth International Biometric Conference, Kobe, Japan, Sunday 26th August 2012 to Friday 31st August 2012. 2012b ; 25.

36. Barukčić I. The Mathematical Formula of the Causal Relationship k International Journal of Applied Physics and Mathematics. 2016c ; 6(2): 45-65. https://doi.org/10.17706/ijapm.2016.6.2.45-65

37. Barukčić I. Theoriae causalitatis principia mathematica. Norderstedt: Books on Demand, 2017a.

38. Barukčić I. Die Kausalität, edn 1989. Norderstedt: Books on Demand, 2017b.

39. Barukčić I. Anti Bohr - Quantum Theory and Causality. International Journal of Applied Physics and Mathematics. 2017c ; 7(2): 93-111. https://doi.org/10.17706/ijapm.2017.7.2.93-111

40. Barukčić I. Helicobacter pylori-The Cause of Human Gastric Cancer. Journal of Biosciences and Medicines. 2017d ; 05(02): 1-9. https://doi.org/10.4236/jbm.2017.52001

41. Barukčić I. Epstein Bar Virus-The Cause of Hodgkin's Lymphoma Journal of Biosciences and Medicines. 2018a ; 06(01): 75-100. https://doi.org/10.4236/jbm.2018.61008

42. Barukčić I. Fusobacterium nucleatum -The Cause of Human Colorectal Cancer. Journal of Biosciences and Medicines. 2018b ; 06(03): 31-69. https://doi.org/10.4236/jbm.2018.63004

43. Barukčić I. Human Papillomavirus-The Cause of Human Cervical Cancer. Journal of Biosciences and Medicines. 2018d ; 06(04): 106-125. https://doi.org/10.4236/jbm.2018.64009

44. Barukčić I. Helicobacter Pylori is the Cause of Gastric Cancer. Modern Health Science. 2018e ; 1(1): 43-50. https://doi. org/10.30560/mhs.v1n1p43

45. Barukčić I. Mycobacterium Avium Subspecies Paratuberculosis: The Cause Of Crohn's Disease. Modern Health Science. 2018e ; 1(1): 19-34. https://doi.org/10.30560/mhs.v1n1p19.

46. Barukčić I. Gastric Cancer and Epstein-Barr Virus Infection. Modern Health Science. 2018f ; 1(2): 1-18. https://doi.org/10.30560/mhs. v1n2p1

47. Barukčić I. Human Cytomegalovirus is the Cause of Glioblastoma Multiforme. Modern Health Science. $2018 \mathrm{~g} ; 1(2)$ : p19. https://doi. org/10.30560/mhs.v1n2p19

48. Barukčić K \& Barukčić I. Epstein Barr Virus-The Cause of Multiple Sclerosis. Journal of Applied Mathematics and Physics. 2016 ; 04(06): 1042-1053. https://doi.org/10.4236/jamp.2016.46109

49. Pearson K. Mathematical Contributions to the Theory of Evolution. III. Regression, Heredity, and Panmixia. Philosophical Transactions of the Royal Society A: Mathematical, Physical and Engineering Sciences. 1896 ; 187(0): 253-318. https://doi.org/10.1098/rsta.1896.0007

50. Bravais A. Analyse mathématique sur les probabilités d es erreurs de situation d'un point. Mémoires Présentées Par Divers Savants À L'Académie Royale Des Sciences De L'Institut De France. 1846; 9: 255-332.

51. Sober E. Venetian Sea Levels, British Bread Prices, and the Principle of the Common Cause. The British Journal for the Philosophy of Science. 2001 ; 52(2): 331-346. https://doi. org/10.1093/bjps/52.2.331
52. Huygens $\mathrm{C}$ \& van Schooten F. Exercitationum mathematicarum liber primus [- quintus] De ratiociniis in ludo alae. Lugdunum Batavorum [Leiden]: ex officina Johannis Elsevirii, 1657.

53. Pearson K. XV. On certain properties of the hypergeometrical series, and on the fitting of such series to observation polygons in the theory of chance. The London, Edinburgh, and Dublin Philosophical Magazine and Journal of Science. 1899 ; 47(285): 236-246. https://doi.org/10.1080/14786449908621253

54. Gonin HT. XIV. The use of factorial moments in the treatment of the hypergeometric distribution and in tests for regression. The London, Edinburgh, and Dublin Philosophical Magazine and Journal of Science. 1936 ; 21(139): 215-226. https://doi. org/10.1080/14786443608561573

55. Hald A, Ed. A history of probability and statistics and their applications before 1750. New York, NY: Wiley, 2005.

56. Anderson RJ. Dissertation. The chi square approximation to the hypergeometric probability distribution. North Texas State University. 1982(8): 1-162. https://www.ncbi.nlm.nih.gov/ pubmed/1085148

57. Cornfield J. A Method of Estimating Comparative Rates from Clinical Data. Applications to Cancer of the Lung, Breast, and Cervix. JNCl: Journal of the National Cancer Institute. 1951 ; 11(6): 1269-1275. https://doi.org/10.1093/jnci/11.6.1269

58. Edwards AWF. The Measure of Association in a $2 \times 2$ Table. Journal of the Royal Statistical Society. Series A (General). 1963 ; 126(1): 109. https://doi.org/10.2307/2982448

59. Mosteller F. Association and Estimation in Contingency Tables. Journal of the American Statistical Association. 1968 ; 63(321): 1. https://doi.org/10.2307/2283825

60. Pagano M \& Gauvreau K. Principles of Biostatistics, Second Edition, edn 2. Milton: CRC Press, 2018.

61. Yule GU. On the Association of Attributes in Statistics: With Illustrations from the Material of the Childhood Society, \&c. Philosophical Transactions of the Royal Society A: Mathematical, Physical and Engineering Sciences. 1900 ; 194(252-261): 257-319. https://doi.org/10.1098/rsta.1900.0019

62. Warrens MJ. On Association Coefficients for $2 \times 2$ Tables and Properties That Do Not Depend on the Marginal Distributions. Psychometrika. 2008 ; 73(4): 777-789. https://doi. org/10.1007/s11336-008-9070-3 https://www.ncbi.nlm.nih.gov/ pubmed/20046834

63. Pearson K \& Heron D. On Theories of Association. Biometrika. $1913 ;$ 9(1-2): 159-315. https://doi.org/10.1093/biomet/9.1-2.159

64. Altman DG. Practical statistics for medical research, edn 1. London: Chapman and Hall, 1991.

65. Yamane T, Ed. Statistics. An introductory analysis: Harper International Edition, 1964.

66. Sachs L. Angewandte Statistik. Berlin, Heidelberg: Springer Berlin Heidelberg, 1992.

67. Isserlis L. On the Value of a Mean as Calculated from a Sample. Journal of the Royal Statistical Society. $1918 ; 81(1): 75$. https://doi. org/10.2307/2340569

68. Pearson K. X. On the criterion that a given system of deviations from the probable in the case of a correlated system of variables is such that it can be reasonably supposed to have arisen from random sampling. The London, Edinburgh, and Dublin Philosophical Magazine and Journal of Science. 1900 ; 50(302): 157-175. https://doi.org/10.1080/14786440009463897

69. Rumke CL. Implications of the Statement: No Side Effects Were Observed. The New England journal of medicine. $1975 ; 292(7)$ : 372-373. https://doi.org/10.1056/NEJM197502132920723

70. Louis TA. Confidence Intervals for a Binomial Parameter after Observing No Successes. The American Statistician. 1981 ; 35(3): 154. https://doi.org/10.1080/00031305.1981.10479337

71. Hanley JA. If Nothing Goes Wrong, Is Everything All Right? JAMA. 1983 ; 249(13): 1743. https://doi.org/10.1001/ jama.1983.03330370053031

72. Jovanovic BD \& Levy PS. A Look at the Rule of Three. The American Statistician. 1997 ; 51(2): 137-139. https://doi.org/10.108 0/00031305.1997.10473947

73. Yates F. Contingency Tables Involving Small Numbers and the $X$ 2 Test. The Journal of the Royal Statistical Society (Supplement). 1934 ; 1(2): 217-235. https://doi.org/10.2307/2983604 
74. Phillips PE, Waxman J, Hirshaut $Y$ \& Kaplan MH. Virus antibody levels and delayed hypersensitivity in rheumatoid arthritis. Annals of the rheumatic diseases. $1976 ; 35(2)$ : 152-154. https://www.ncbi. nlm.nih.gov/pubmed/182092

75. $\mathrm{Ng} \mathrm{KC}$, Brown KA, Perry JD \& Holborow EJ. Anti-RANA antibody: a marker for seronegative and seropositive rheumatoid arthritis. Lancet (London, England). 1980 ; 1(8166): 447-449. https://doi. org/10.1016/S0140-6736(80)90997-6 https://www.ncbi.nlm.nih.gov/ pubmed/6102183.

76. Ferrell PB, Aitcheson CT, Pearson GR \& Tan EM. Seroepidemiological study of relationships between Epstein-Barr virus and rheumatoid arthritis. The Journal of clinical investigation. $1981 ; 67(3)$ : 681-687. https://doi.org/10.1172/JCl110083 https:// www.ncbi.nlm.nih.gov/pubmed/6259207

77. Venables PJ, Roffe LM, Erhardt CC, Maini RN, Edwards JM \& Porter AD. Titers of antibodies to RANA in rheumatoid arthritis and normal sera. Relationship to Epstein-Barr virus infection. Arthritis and rheumatism. 1981 ; 24(12): 1459-1468. https://www.ncbi.nlm. nih.gov/pubmed/6275861

78. Nakabayashi K, Saito M, Nagasawa T \& Takada M. Antibodies to rheumatoid arthritis nuclear antigen (RANA) in Japanese patients with rheumatoid arthritis. Rheumatology international. $1985 ; 5(2)$ : 61-67. https://www.ncbi.nlm.nih.gov/pubmed/3885372

79. Venables PJ, Ross MG, Charles PJ, Melsom RD, Griffiths PD \& Maini RN. A seroepidemiological study of cytomegalovirus and Epstein-Barr virus in rheumatoid arthritis and sicca syndrome. Annals of the rheumatic diseases. 1985 ; 44(11): 742-746. https:// www.ncbi.nlm.nih.gov/pubmed/2998290

80. Sculley TB, Pope JH \& Hazelton RA. Correlation between the presence of antibodies to the Epstein-Barr virus nuclear antigen type 2 and antibodies to the rheumatoid arthritis nuclear antigen in patients with rheumatoid arthritis. Arthritis and rheumatism. 1986 ; 29(8): 964-970. https://www.ncbi.nlm.nih.gov/pubmed/3017369

81. Yao QY, Rickinson AB, Gaston JS \& EPSTEIN MA. Disturbance of the Epstein-Barr virus-host balance in rheumatoid arthritis patients: a quantitative study. Clinical and Experimental Immunology. 1986 ; 64(2): 302-310. https://www.ncbi.nlm.nih.gov/pubmed/3017620

82. Musiani M, Zerbini M, Ferri S, Plazzi M, Gentilomi G \& La Placa M. Comparison of the immune response to Epstein-Barr virus and cytomegalovirus in sera and synovial fluids of patients with rheumatoid arthritis. Annals of the rheumatic diseases. 1987 ; 46(11): 837-842. https://www.ncbi.nlm.nih.gov/pubmed/2827590

83. Shirodaria PV, Haire M, Fleming E, Merrett JD, Hawkins SA \& Roberts SD. Viral antibody titers. Comparison in patients with multiple sclerosis and rheumatoid arthritis. Archives of neurology. 1987 ; 44(12): 1237-1241. https://doi.org/10.1001/ archneur.1987.00520240019006 https://www.ncbi.nlm.nih.gov/ pubmed/2823754

84. Youinou P, Buisson M, Berthelot JM, Jamin C, Le Goff P, Genoulaz O, Lamour A, Lydyard PM \& Seigneurin JM. Anti-Epstein-Barr virusnuclear antigen-1, $-2 \mathrm{~A}$ and $-2 \mathrm{~B}$ antibodies in rheumatoid arthritis patients and their relatives. Autoimmunity. 1992 ; 13(3): 225-231. https://www.ncbi.nlm.nih.gov/pubmed/1335296

85. Zhang L, Nikkari S, Skurnik M, Ziegler T, Luukkainen R, Möttönen $T$ \& Toivanen $P$. Detection of herpesviruses by polymerase chain reaction in lymphocytes from patients with rheumatoid arthritis. Arthritis and rheumatism. 1993 ; 36(8): 1080-1086. https://www. ncbi.nlm.nih.gov/pubmed/8343184

86. Mousavi-Jazi M, Boström L, Lövmark C, Linde A, Brytting M \& Sundqvist VA. Infrequent detection of cytomegalovirus and EpsteinBarr virus DNA in synovial membrane of patients with rheumatoid arthritis. The Journal of rheumatology. 1998 ; 25(4): 623-628. https://www.ncbi.nlm.nih.gov/pubmed/9558160

87. Davies JM, Mackay IR \& Rowley MJ. Rheumatoid arthritis sera react with a phage-displayed peptide selected by a monoclonal antibody to type II collagen that has homology to EBNA-1. Autoimmunity. 1999 ; 30(1): 53-59. https://www.ncbi.nlm.nih.gov/ pubmed/10433095

88. Saal JG, Krimmel M, Steidle M, Gerneth F, Wagner S, Fritz P, Koch S, Zacher J, Sell S, Einsele H \& Müller CA. Synovial Epstein-Barr virus infection increases the risk of rheumatoid arthritis in individuals with the shared HLA-DR4 epitope. Arthritis and rheumatism. 1999 ; 42(7): 1485-1496. https://doi.org/10.1002/1529-0131(199907)42:7<1485:AID-
ANR24>3.0.CO;2-7 https://www.ncbi.nlm.nih.gov/ pubmed/10403278

89. Zhang $X$, Li B, Liu Y \& Jiang M. Clinical study on antibodies against EBV in sera of patients with rheumatoid arthritis. Zhongguo yi xue ke xue yuan xue bao. Acta Academiae Medicinae Sinicae. 1999 ; 21(1): 8-12. https://www.ncbi.nlm.nih.gov/pubmed/12569633

90. Blaschke S, Schwarz G, Moneke D, Binder L, Müller G \& Reuss-Borst M. Epstein-Barr virus infection in peripheral blood mononuclear cells, synovial fluid cells, and synovial membranes of patients with rheumatoid arthritis. The Journal of rheumatology. 2000 ; 27(4): 866-873. https://www.ncbi.nlm.nih.gov/ pubmed/10782808

91. Takeda T, Mizugaki Y, Matsubara L, Imai S, Koike T \& Takada K. Lytic Epstein-Barr virus infection in the synovial tissue of patients with rheumatoid arthritis. Arthritis and rheumatism. 2000 ; 43(6): 1218-1225. https://doi.org/10.1002/15290131(200006)43:6<1218:AID-ANR4>3.0.CO;2-2 https://www.ncbi. nlm.nih.gov/pubmed/10857780

92. Jørgensen KT, Wiik A, Pedersen M, Hedegaard CJ, Vestergaard BF, Gislefoss RE, Kvien TK, Wohlfahrt J, Bendtzen K \& Frisch M. Cytokines, autoantibodies and viral antibodies in premorbid and postdiagnostic sera from patients with rheumatoid arthritis: case-control study nested in a cohort of Norwegian blood donors. Annals of the rheumatic diseases. $2008 ; 67(6)$ : 860-866. https:// doi.org/10.1136/ard.2007.073825 https://www.ncbi.nlm.nih.gov/ pubmed/17644543

93. Lünemann JD, Frey O, Eidner T, Baier M, Roberts S, Sashihara J, Volkmer R, Cohen JI, Hein G, Kamradt T \& Münz C. Increased frequency of EBV-specific effector memory CD8+ T cells correlates with higher viral load in rheumatoid arthritis. Journal of immunology (Baltimore, Md. 1950). 2008 ; 181(2): 991-1000. https://doi. org/10.4049/jimmunol.181.2.991 https://www.ncbi.nlm.nih.gov/ pubmed/18606650

94. Us T, Cetin E, Kaşifoğlu N, Kaşifoğlu T \& Akgün Y. Romatoid Artrit ve Sistemik Lupus Eritematozuslu Hastalarda Epstein-Barr Virus ve Herpes Simpleks Virus Göstergelerinin Serolojik ve Moleküler Yöntemlerle Araştırılması. Mikrobiyoloji bulteni. 2011 ; 45(4): 677-683. https://www.ncbi.nlm.nih.gov/pubmed/22090298

95. Yazbek MA, Barros-Mazon Sd, Rossi CL, Londe AC, Costallat LTL \& Bertolo MB. Association analysis of anti-Epstein-Barr nuclear antigen-1 antibodies, anti-cyclic citrullinated peptide antibodies, the shared epitope and smoking status in Brazilian patients with rheumatoid arthritis. Clinics (Sao Paulo, Brazil). 2011 ; 66(8): 1401-1406. https://www.ncbi.nlm.nih.gov/pubmed/21915491

96. Chiu W-C, Chen C-M, Cheng T-T, You H-L, Yu S-F, Weng L-H, Huang H-Y, Huang C-C \& Chen C-J. EBV-encoded small RNA1 and nonresolving inflammation in rheumatoid arthritis. The Kaohsiung journal of medical sciences. 2013 ; 29(11): 606-610. https://doi.org/10.1016/j.kjms.2013.04.002 https://www.ncbi.nlm.nih. gov/pubmed/24183354

97. Erre GL, Mameli G, Cossu D, Muzzeddu B, Piras C, Paccagnini D, Passiu G \& Sechi LA. Increased Epstein-Barr Virus DNA Load and Antibodies Against EBNA1 and EA in Sardinian Patients with Rheumatoid Arthritis. Viral immunology. 2015 ; 28(7): 385-390. https://doi.org/10.1089/vim.2015.0035 https://www.ncbi.nlm.nih. gov/pubmed/26083265

98. Mahabadi M, Faghihiloo E, Alishiri GH, Ataee MH \& Ataee RA. Detection of Epstein-Barr virus in synovial fluid of rheumatoid arthritis patients. Electronic physician. 2016 ; 8(3): 2181-2186. https://doi.org/10.19082/2181 https://www.ncbi.nlm.nih.gov/ pubmed/27123228

99. Sherina N, Hreggvidsdottir HS, Bengtsson C, Hansson M, Israelsson L, Alfredsson L \& Lundberg K. Low levels of antibodies against common viruses associate with anti-citrullinated protein antibody-positive rheumatoid arthritis; implications for disease aetiology. Arthritis research \& therapy. $2017 ; 19(1): 219$. https:// doi.org/10.1186/s13075-017-1423-9 https://www.ncbi.nlm.nih.gov/ pubmed/28962582

100.Epstein M.A., Barr Y.M. \& Achong B.G. Virus particles in cultured lymphoblasts from Burkitt's lymphoma. Lancet (London, England). 1964 ; 1(7335): 702-703. https://doi.org/10.1016/S01406736(64)91524-7 https://www.ncbi.nlm.nih.gov/pubmed/14107961

101.Costenbader KH \& Karlson EW. Epstein-Barr virus and rheumatoid arthritis: is there a link? Arthritis research \& therapy. $2006 ; 8(1)$ : 
204. https://doi.org/10.1186/ar1893 https://www.ncbi.nlm.nih.gov/ pubmed/16542469

102.Ball RJ, Avenell A, Aucott L, Hanlon P \& Vickers MA. Systematic review and meta-analysis of the sero-epidemiological association between Epstein-Barr virus and rheumatoid arthritis. Arthritis research \& therapy. $2015 ; 17): 274$. https://doi.org/10.1186/s13075015-0755-6 https://www.ncbi.nlm.nih.gov/pubmed/26416719

103.Arnett FC, Edworthy SM, Bloch DA, McShane DJ, Fries JF, Cooper NS, Healey LA, Kaplan SR, Liang MH \& Luthra HS. The American Rheumatism Association 1987 revised criteria for the classification of rheumatoid arthritis. Arthritis and rheumatism. $1988 ; 31(3)$ : 315-324. https://www.ncbi.nlm.nih.gov/pubmed/3358796

104.Mankarious S, Lee M, Fischer S, Pyun KH, Ochs HD, Oxelius VA \& Wedgwood RJ. The half-lives of IgG subclasses and specific antibodies in patients with primary immunodeficiency who are receiving intravenously administered immunoglobulin. The Journal of laboratory and clinical medicine. 1988 ; 112(5): 634-640. https:// www.ncbi.nlm.nih.gov/pubmed/3183495

105.Paschale M de \& Clerici P. Serological diagnosis of Epstein-Barr virus infection: Problems and solutions. World journal of virology. 2012 ; 1(1): 31-43. https://doi.org/10.5501/wjv.v1.i1.31 https://www. ncbi.nlm.nih.gov/pubmed/24175209

106. Thorley-Lawson DA. Epstein-Barr virus: exploiting the immune system. Nature reviews. Immunology. $2001 ; 1(1): 75-82$. https://doi.org/10.1038/35095584 https://www.ncbi.nlm.nih.gov/ pubmed/11905817

107.Sculley TB, Walker PJ, Moss DJ \& Pope JH. Identification of multiple Epstein-Barr virus-induced nuclear antigens with sera from patients with rheumatoid arthritis. Journal of virology. 1984 ; 52(1): 88-93. https://www.ncbi.nlm.nih.gov/pubmed/6090712

108. Trier NH, Holm BE, Heiden J, Slot O, Locht H, Lindegaard H, Svendsen A, Nielsen CT, Jacobsen S, Theander E \& Houen G. Antibodies to a strain-specific citrullinated Epstein-Barr virus peptide diagnoses rheumatoid arthritis. Scientific reports. 2018 ; 8(1): 3684. https://doi.org/10.1038/s41598-018-22058-6 https:// www.ncbi.nlm.nih.gov/pubmed/29487382

109. Hazelton RA, Sculley TB \& Pope JH. The prevalence of antibodies to an Epstein-Barr virus-induced polypeptide (EBNA2 ) in the sera of rheumatoid arthritic families. British journal of rheumatology. 1987 ; 26(3): 193-196. https://www.ncbi.nlm.nih.gov/ pubmed/3034370

110. Baecklund E, Iliadou A, Askling J, Ekbom A, Backlin C, Granath F, Catrina Al, Rosenquist R, Feltelius N, Sundström C \& Klareskog L. Association of chronic inflammation, not its treatment, with increased lymphoma risk in rheumatoid arthritis. Arthritis and rheumatism. 2006 ; 54(3): 692-701. https://doi.org/10.1002/ art.21675 https://www.ncbi.nlm.nih.gov/pubmed/16508929

111. Kolmogoroff A. Grundbegriffe der Wahrscheinlichkeitsrechnung. Berlin, Heidelberg: Springer Berlin Heidelberg, 1933.

112. Takahashi Y, Murai C, Shibata S, Munakata Y, Ishii T, Ishii K, Saitoh T, Sawai T, Sugamura K \& Sasaki T. Human parvovirus B19 as a causative agent for rheumatoid arthritis. Proceedings of the National Academy of Sciences of the United States of America. 1998 ; 95(14): 8227-8232. https://www.ncbi.nlm.nih.gov/ pubmed/9653169

113. Kerr JR, Cartron JP, Curran MD, Moore JE, Elliott JR \& Mollan RA. A study of the role of parvovirus B19 in rheumatoid arthritis. British journal of rheumatology. 1995 ; 34(9): 809-813. https://www.ncbi. nlm.nih.gov/pubmed/7582718

114. Naciute M, Mieliauskaite D, Rugiene R, Nikitenkiene R, Jancoriene L, Mauricas M, Nora-Krukle Z, Murovska M \& Girkontaite I. Frequency and significance of parvovirus B19 infection in patients with rheumatoid arthritis. The Journal of general virology. 2016 ; 97(12): 3302-3312. https://doi.org/10.1099/jgv.0.000621 https:// www.ncbi.nlm.nih.gov/pubmed/27902343.

115. Fox RI, Chilton T, Rhodes $\mathrm{G}$ \& Vaughan JH. Lack of reactivity of rheumatoid arthritis synovial membrane DNA with cloned Epstein Barr virus DNA probes. Journal of immunology (Baltimore, Md. 1950). 1986 ; 137(2): 498-501. https://www.ncbi.nlm.nih.gov/ pubmed/3013992

116. Balandraud N, Meynard JB, Auger I, Sovran H, Mugnier B, Reviron D, Roudier J \& Roudier C. Epstein-Barr virus load in the peripheral blood of patients with rheumatoid arthritis: accurate quantification using real-time polymerase chain reaction. Arthritis and rheumatism. 2003 ; 48(5): 1223-1228. https://doi.org/10.1002/ art.10933 https://www.ncbi.nlm.nih.gov/pubmed/12746895

117. Gall JG \& Pardue ML. Formation and detection of RNA-DNA hybrid molecules in cytological preparations. Proceedings of the National Academy of Sciences of the United States of America. $1969 ; 63(2)$ : 378-383. https://doi.org/10.1073/pnas.63.2.378 https://www.ncbi. nlm.nih.gov/pubmed/4895535

118. Fan H \& Gulley ML. Molecular Methods for Detecting Epstein-Barr Virus (Part I) In Situ Hybridization to Epstein-Barr Virus-Encoded RNA (EBER) Transcripts. Methods in molecular medicine. 2001; 49): 301-311. https://doi.org/10.1385/1-59259-081-0:301 https:// www.ncbi.nlm.nih.gov/pubmed/21370148

119. Mehraein Y, Lennerz C, Ehlhardt S, Remberger K, Ojak A \& Zang $K D$. Latent Epstein-Barr virus (EBV) infection and cytomegalovirus (CMV) infection in synovial tissue of autoimmune chronic arthritis determined by RNA- and DNA-in situ hybridization. Modern pathology an official journal of the United States and Canadian Academy of Pathology, Inc. 2004 ; 17(7): 781-789. https://doi. org/10.1038/modpathol.3800119 https://www.ncbi.nlm.nih.gov/ pubmed/15044921

120.DIXON FJ, TALMAGE DW, MAURER PH \& DEICHMILLER M. The half-life on homologous gamma globulin (antibody) in several species. The Journal of experimental medicine. 1952 ; 95(5): 313-318. https://www.ncbi.nlm.nih.gov/pubmed/12981216

121. Toussirot E \& Roudier J. Pathophysiological links between rheumatoid arthritis and the Epstein-Barr virus: an update. Joint, bone, spine revue du rhumatisme. 2007 ; 74(5): 418-426. https:// doi.org/10.1016/j.jbspin.2007.05.001 https://www.ncbi.nlm.nih.gov/ pubmed/17625943

122.Landré-Beauvais AJ. The first description of rheumatoid arthritis. Unabridged text of the doctoral dissertation presented in 1800. Joint Bone Spine 2001; 68 (2): 130-143. https://doi.org/10.1016/ S1297-319X(00)00247-5 https://www.ncbi.nlm.nih.gov/ pubmed/11324929

123.Entezami P, Fox DA, Clapham PJ \& Chung KC. Historical perspective on the etiology of rheumatoid arthritis. Hand clinics 2011; 27 (1): 1-10. https://doi.org/10.1016/j.hcl.2010.09.006 https:// www.ncbi.nlm.nih.gov/pubmed/21176794 